Marquette University

e-Publications@Marquette

\title{
Tetranuclear Group 7/8 Mixed-Metal and Open Trinuclear Group 7 Metal Carbonyl Clusters Bearing Bridging 2-mercapto-1-methylimidazole Ligands
}

\author{
Shishir Ghosh \\ Jahangirnagar University \\ Shariff E. Kabir \\ Jahangirnagar University \\ Salina Pervin \\ Jahangirnagar University \\ Arun K. Raha \\ Jahangirnagar University \\ G. M. Golzar Hossain \\ University of Dhaka
}

See next page for additional authors

Follow this and additional works at: https://epublications.marquette.edu/chem_fac

Part of the Chemistry Commons

\section{Recommended Citation}

Ghosh, Shishir; Kabir, Shariff E.; Pervin, Salina; Raha, Arun K.; Hossain, G. M. Golzar; Haworth, Daniel T.; Lindeman, Sergey V.; Bennett, Dennis W.; Siddiquee, Tasneem; Salassa, Luca; and Roesky, Herbert W., "Tetranuclear Group 7/8 Mixed-Metal and Open Trinuclear Group 7 Metal Carbonyl Clusters Bearing Bridging 2-mercapto-1-methylimidazole Ligands" (2009). Chemistry Faculty Research and Publications. 609.

https://epublications.marquette.edu/chem_fac/609 


\section{Authors}

Shishir Ghosh, Shariff E. Kabir, Salina Pervin, Arun K. Raha, G. M. Golzar Hossain, Daniel T. Haworth, Sergey V. Lindeman, Dennis W. Bennett, Tasneem Siddiquee, Luca Salassa, and Herbert W. Roesky 
Marquette University

e-Publications@Marquette

\section{Chemistry Faculty Research and Publications/Department of Chemistry}

This paper is NOT THE PUBLISHED VERSION; but the author's final, peer-reviewed manuscript. The published version may be accessed by following the link in th citation below.

Dalton Transactions, No. 18 (2009): 3510-3518. DOI. This article is @ Royal Society of Chemistry and permission has been granted for this version to appear in e-Publications@Marquette. Royal Society of Chemistry does not grant permission for this article to be further copied/distributed or hosted elsewhere without the express permission from Royal Society of Chemistry.

\section{Tetranuclear Group 7/8 Mixed-Metal and Open Trinuclear Group 7 Metal Carbonyl Clusters Bearing Bridging 2-mercapto-1-methylimidazole Ligands ${ }^{ \pm}$}

Shishir Ghosh

Department of Chemistry, Jahangirnagar University, Savar, Bangladesh

Shariff E. Kabir

Department of Chemistry, Jahangirnagar University, Savar, Bangladesh

Salina Pervin

Department of Chemistry, Jahangirnagar University, Savar, Bangladesh

Arun K. Raha

Department of Chemistry, Jahangirnagar University, Savar, Bangladesh

G. M. Golzar Hossain

Department of Chemistry, Dhaka University, Dhaka, Bangladesh

Daniel T. Haworth

Department of Chemistry, Marquette University, Milwaukee, WI

Sergey V. Lindeman

Department of Chemistry, Marquette University, Milwaukee, WI

Dennis W. Bennett

Department of Chemistry, University of Wisconsin-Milwaukee, Milwaukee, WI 
Tasneem A. Siddiquee

Department of Chemistry, University of Wisconsin-Milwaukee, Milwaukee, WI

Luca Salassa

Department of Chemistry IFM, University of Turin, Turin, Italy

Herbert W. Roesky

Institute of Inorganic Chemistry, Georg-August University of Goettingen, Goettingen, Germany

\begin{abstract}
The reactivity of group 7 metal dinuclear carbonyl complexes $\left[\mathrm{M}_{2}(\mathrm{CO})_{6}\left(\mu-\mathrm{SN}_{2} \mathrm{C}_{4} \mathrm{H}_{5}\right)_{2}\right](\mathbf{1}, \mathrm{M}=\mathrm{Re} ; \mathbf{2}, \mathrm{M}=\mathrm{Mn})$ toward group 8 metal trinuclear carbonyl clusters were examined. Reactions of 1 and $\mathbf{2}$ with $\left[\mathrm{Os}_{3}(\mathrm{CO})_{10}(\mathrm{NCMe})_{2}\right]$ in refluxing benzene furnished the tetranuclear mixed-metal clusters $\left[\mathrm{Os}_{3} \mathrm{Re}(\mathrm{CO})_{13}\left(\mu_{3}-\mathrm{SN}_{2} \mathrm{C}_{4} \mathrm{H}_{5}\right)\right](3)$ and $\left[\mathrm{Os}_{3} \mathrm{Mn}(\mathrm{CO})_{13}\left(\mu_{3}-\mathrm{SN}_{2} \mathrm{C}_{4} \mathrm{H}_{5}\right)\right]$ (4), respectively. Similar treatment of 1 and $\mathbf{2}$ with $\mathrm{Ru}_{3}(\mathrm{CO})_{12}$ yielded the ruthenium analogs $\left[R u_{3} R e(C O)_{13}\left(\mu_{3}-S_{2} C_{4} H_{5}\right)\right](5)$, and $\left[R u_{3} \mathrm{Mn}(\mathrm{CO})_{13}\left(\mu_{3}-\mathrm{SN}_{2} \mathrm{C}_{4} \mathrm{H}_{5}\right)\right](6)$, but in the case of 2 a secondary product $\left[\mathrm{Mn}_{3}(\mathrm{CO})_{10}(\mu-\mathrm{Cl})\left(\mu_{3}-\mathrm{SN}_{2} \mathrm{C}_{4} \mathrm{H}_{5}\right)_{2}\right]$ (7) was also formed. Compounds 3-6 have a butterfly core of four metal atoms with the $\mathrm{M}(\mathrm{Mn}$ or $\mathrm{Re}$ ) at a wingtip of the butterfly and containing a noncrystallographic mirror plane of symmetry. This result provides a potential method for the synthesis of a series of new group $7 / 8$ mixed metal complexes containing a bifunctional heterocyclic ligand. Compound $\mathbf{7}$ is a unique example of a 54-electron trimanganese complex having bridging 2-mercapto-1-methylimidazolate and chloride ligands. Interestingly, the reaction of 1 with $\mathrm{Fe}_{3}(\mathrm{CO})_{12}$ at $70-75^{\circ} \mathrm{C}$ furnished the tri- and dirhenium complexes $\left[\operatorname{Re}_{3}(\mathrm{CO})_{10}(\mu-\mathrm{H})\left(\mu_{3}-\right.\right.$ $\left.\left.\mathrm{SN}_{2} \mathrm{C}_{4} \mathrm{H}_{5}\right)_{2}\right](8)$ and $\left[\mathrm{Re}_{2}(\mathrm{CO})_{6}\left(\mathrm{~N}_{2} \mathrm{C}_{4} \mathrm{H}_{5}\right)\left(\mu-\mathrm{SN}_{2} \mathrm{C}_{4} \mathrm{H}_{5}\right)_{2}\right](9)$, respectively instead of the expected formation of the mixed-metal clusters. The former is an interesting example of a 52-electron trirhenium-hydridic complex containing bridging 2-mercapto-1-methylimidazolate ligand, while the latter can be viewed as a 1methylimidazole adduct of $\mathbf{1}$. No mixed Fe-Re complexes were produced in this reaction. The molecular structures of the new compounds 3-5 and 7-9 were established by single-crystal X-ray diffraction analyses and the DFT studies of compounds $\mathbf{5}, \mathbf{7}$ and $\mathbf{8}$ are reported.
\end{abstract}

\title{
Introduction
}

Over the last three decades, considerable attention has been focused on the chemistry of mixed-metal clusters of low-valent transition metals due to their unique structural properties and various potential applications resulting from having two metals with different chemical properties in close proximity. $\frac{1-4}{}$ The greatest stimulus for the development of this field of research is the cooperative reactivity of two or more coordination centers, which offer attractive perspective in stoichiometric and catalytic transformations. $\frac{5-}{5}$ $\underline{18}$ In addition, heterobimetallic complexes may combine the catalytic features of each metal to provide new and unique reactivity that is inaccessible by the homobimetallic systems. $\underline{\underline{19}-21}$

Tetranuclear clusters with a butterfly structure have received much attention because of their intermediary position between tetrahedral and square-planar clusters. $\stackrel{22,23}{2}$ They have been studied as intermediates in homogeneous catalytic processes, $\underline{\underline{23}-25}$ and also considered as a model for chemisorption of small molecules. ${ }^{26}$ Information about the structural properties of the butterfly framework as well as the chemistry of coordinated ligands can be easily obtained as both metal atoms and ligands can vary widely in butterflytype clusters. $\underline{23}$ 
Recently, we reported a series of group 6 and 7 mixed-metal complexes containing a 2-mercapto-1methylimidazolate ligand ${ }^{27}$ (Scheme 1). 2-Mercapto-1-methylimidazole is a bifunctional ligand with great coordinative flexibility and versatility and introduces novel reactivities to the resultant complexes, many of which possess important biological and industrial applications. $\frac{28-33}{A}$ number of group 7 and 8 heterobimetallic complexes have been cited in literature. Deeming et al. reported a series of Re-Ru mixedmetal complexes from the reaction of $\left[\operatorname{Re}_{2}(\mathrm{CO})_{6}(\mu-\mathrm{pyS})_{2}\right]$ and $\mathrm{Ru}_{3}(\mathrm{CO})_{12} \cdot \frac{34,35}{}$ Knight and Mays documented group 7 and 8 tri- and tetrameric mixed-metal clusters obtained from the reaction of the neutral metal carbonyls $\mathrm{M}_{3}(\mathrm{CO})_{12}(\mathrm{M}=\mathrm{Fe}, \mathrm{Ru}, \mathrm{Os})$ with the metal carbonyl anions $\left[\mathrm{M}^{\prime}(\mathrm{CO})_{5}\right]^{-}\left(\mathrm{M}^{\prime}=\mathrm{Mn}, \mathrm{Re}\right)$. $\underline{36}$ Atwood et al. also reported group 7 and 8 mixed-metal clusters from the electron transfer reaction between mononuclear metal carbonyl anions ( $\left.\left[\mathrm{M}(\mathrm{CO})_{5}\right]^{-}, \mathrm{M}=\mathrm{Mn}, \mathrm{Re}\right)$ and trinuclear clusters $\left(\mathrm{M}_{3}(\mathrm{CO})_{12} ; \mathrm{M}=\mathrm{Fe}, \mathrm{Ru}\right.$, Os). $\frac{37}{-}$ The mixed-metal carbide cluster anions $\left[\mathrm{MnM}_{3} \mathrm{C}(\mathrm{CO})_{13}\right]^{-}(\mathrm{M}=\mathrm{Ru}, \mathrm{Os})$ and the butterfly clusters $\left[\mathrm{Fe}_{3} \mathrm{M}(\mathrm{CO})_{12}\left(\mu_{4}-\mathrm{E}\right)\right][\mathrm{PPN}](\mathrm{E}=\mathrm{O}, \mathrm{S} ; \mathrm{M}=\mathrm{Mn}, \mathrm{Re})$, were reported by Shriver and coworkers. $\frac{38,39}{\text { Struchkov et }}$ al. also documented the tetranuclear mixed Mn-Os cluster [CpMnOs $\left.3(\mathrm{CO})_{11}(\mu-\mathrm{CO})(\mu-\mathrm{H})(\mu-\mathrm{CH}=\mathrm{CHPh})\right]$ from the reaction of the vinylidene complex $\left[\mathrm{Cp}(\mathrm{CO})_{2} \mathrm{Mn}=\mathrm{C}=\mathrm{CHPh}\right]$ with $\left.\left[\mathrm{Os}_{3}(\mathrm{CO})_{10}\right)(\mu-\mathrm{H})_{2}\right] . \stackrel{40}{\text {. }}$ The mixed Fe- $\mathrm{Mn}$ chalcogenide clusters $\left[\mathrm{Et}_{4} \mathrm{~N}\right]\left[\mathrm{MnFe}_{2}(\mathrm{CO})_{10}\left(\mu_{3}-\mathrm{Te}\right)_{2}\right]$ and $\left[\mathrm{Et}_{4} \mathrm{~N}\right]\left[\mathrm{MnFe}_{2}(\mathrm{CO})_{9}\left(\mu_{3}-\mathrm{Se}\right)_{2}\right]$ were reported by Shieh and coworkers $\underline{41}$ from the reaction between $\left[\mathrm{Fe}_{3}(\mathrm{CO})_{9}(\mu-\mathrm{E})_{2}\right](\mathrm{E}=\mathrm{Se}, \mathrm{Te})$ and $\left[\mathrm{Mn}(\mathrm{CO})_{5}\right]^{-}$, while Shaposhnikova et al. $\underline{42}$ reported the mixed Fe-Re cluster $\left[\mathrm{Re}{ }_{2} \mathrm{Fe}(\mathrm{CO})_{9}\left(\mu_{3}-\mathrm{CH}=\mathrm{CHC}_{6} \mathrm{H}_{4}\right)\right]$ from the reaction of $\left[\operatorname{Re}_{2}(\mathrm{CO})_{8}(\mu-\mathrm{H})(\mu-\mathrm{C} \equiv \mathrm{CPh})\right]$ with $\mathrm{Fe}_{3}(\mathrm{CO})_{12}$. Herrmann et al. also reported the mixed Fe-Mn chalcogenide cluster $\left[\mathrm{Cp}^{\prime} \mathrm{MnFe}_{2}(\mathrm{CO})_{6}(\mu-\mathrm{CO})_{2}\left(\mu_{3}-\mathrm{Te}\right)\right]$ obtained from the reaction between the tellurium complex $[(\mu-$ $\left.\mathrm{Te})\left(\mathrm{Cp}^{\prime} \mathrm{Mn}(\mathrm{CO})_{2}\right)_{2}\right]$ and $\mathrm{Fe}_{2}(\mathrm{CO})_{9} \cdot{ }^{43} \mathrm{~A}$ major challenge in the synthesis of group 7 and 8 mixed-metal clusters of desired structural and reactivity features is the lack of suitable methods. As part of our ongoing research into the versatility of 2-mercapto-1-methylimidazole containing metal compounds in the synthesis of mixedmetal complexes, we have explored the possibility of synthesising mixed-metal clusters consisting of group 7 and 8 metal atoms bearing this heterocyclic ligand and the results are reported herein. 


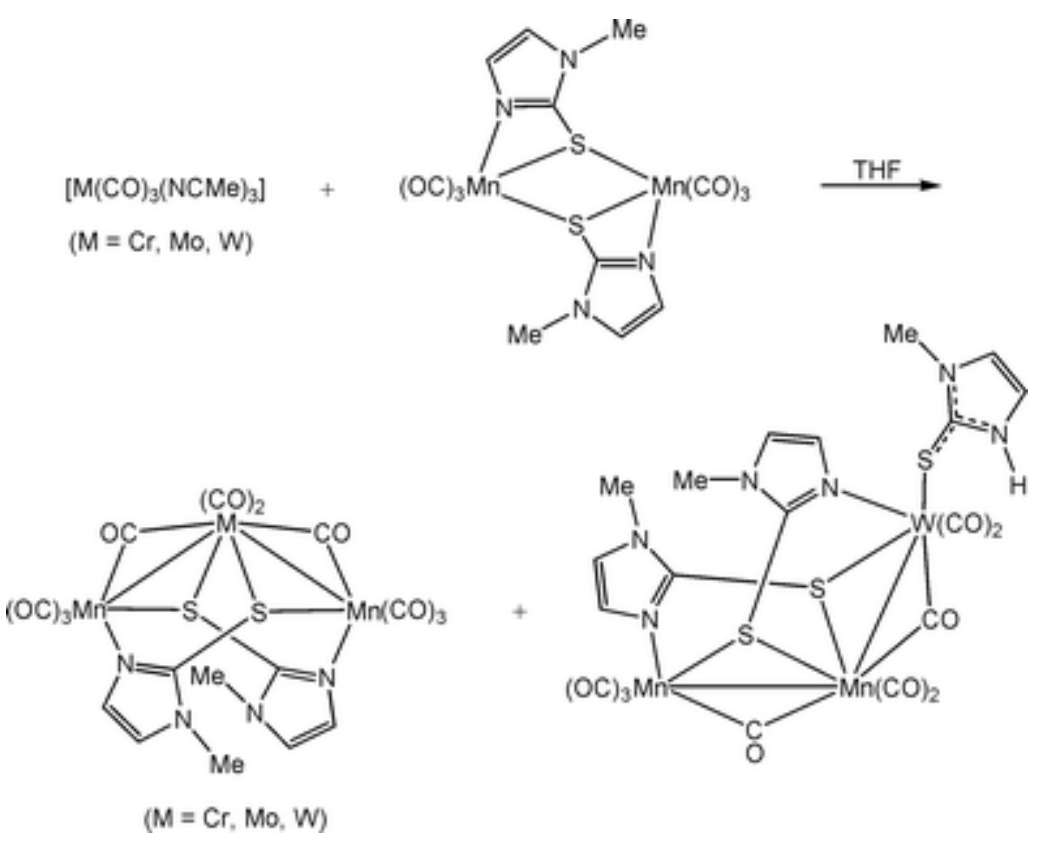

Scheme 1

\section{Results and discussion}

\section{(a) Tetranuclear mixed-metal butterfly clusters}

Reactions of $\left[\mathrm{Os}_{3}(\mathrm{CO})_{10}(\mathrm{NCMe})_{2}\right]$ with $\left[\mathrm{Re}_{2}(\mathrm{CO})_{6}\left(\mu-\mathrm{SN}_{2} \mathrm{C}_{4} \mathrm{H}_{5}\right)_{2}\right](\mathbf{1})$ and $\left[\mathrm{Mn}_{2}(\mathrm{CO})_{6}\left(\mu-\mathrm{SN}_{2} \mathrm{C}_{4} \mathrm{H}_{5}\right)_{2}\right](2)$ in refluxing benzene furnish the mixed-metal clusters [Os 3 Re(CO) $\left.{ }_{13}\left(\mu_{3}-\mathrm{SN}_{2} \mathrm{C}_{4} \mathrm{H}_{5}\right)\right](3)$ and $\left[\mathrm{Os}_{3} \mathrm{Mn}(\mathrm{CO})_{13}\left(\mu_{3^{-}}\right.\right.$ $\left.\left.\mathrm{SN}_{2} \mathrm{C}_{4} \mathrm{H}_{5}\right)\right](4)$ in $60 \%$ and $88 \%$ yields, respectively. The analogous $\operatorname{ReRu_{3}Compound}\left[\mathrm{Ru} \mathrm{C}_{3} \mathrm{Re}(\mathrm{CO})_{13}\left(\mu_{3}-\mathrm{SN}_{2} \mathrm{C}_{4} \mathrm{H}_{5}\right)\right]$ (5) was obtained in $24 \%$ yield via the reaction of 1 with $\mathrm{Ru}_{3}(\mathrm{CO})_{12}$ (Scheme 2). All these compounds have been characterized by elemental analysis, $\underline{\underline{I R} \text { and }}{ }^{1} \underline{H}$ NMR spectroscopic and mass spectroscopic data together with single crystal X-ray diffraction studies. The elemental analyses and mass spectrometric data of these clusters suggested a tetranuclear structure for them. Each of the FAB mass spectra exhibits the respective parent molecular ion peak as well as peaks corresponding to the sequential loss of thirteen carbonyl ligands. The infrared spectra of 3, 4, and $\mathbf{5}$ indicate the presence of only terminal carbonyl ligands. The ${ }^{1} \mathrm{H}$ NMR spectra of 3-5 contain resonances for the heterocyclic ring protons and the methyl protons with appropriate integrations and are similar to those reported for $\mathbf{1}$ and 2. However, the precise attachment of the ligand to these clusters and the exact geometry of the

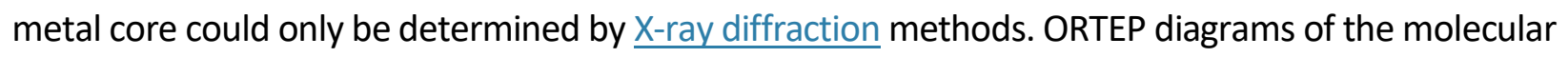
structures of $\mathbf{3}, \mathbf{4}$, and $\mathbf{5}$ are shown in Fig. 1-3, respectively, and selected bond distances and angles are listed in the caption. The clusters $\mathbf{3}, \mathbf{4}$, and $\mathbf{5}$ have the same overall structure. All contain four metal atoms: one manganese or rhenium and three of osmium or ruthenium. The four metal atoms form a butterfly skeleton where the group 7 metal ( $\mathrm{Mn}$ or Re) occupies a wingtip position; whereas, in the known mixedmetal carbide cluster anion $\left[\mathrm{MnOs}_{3} \mathrm{C}(\mathrm{CO})_{13}\right]^{-}$derived from the ketenylidene clusters $\left[\mathrm{Os}_{3}(\mathrm{CO})_{9} \mathrm{CCO}\right]^{2-}$ and $\left[\mathrm{Mn}(\mathrm{CO})_{3}(\mathrm{NCMe})_{3}\right]^{+}$, the manganese atom occupies a hinge position. $\frac{38}{}$ However, in other mixed-metal 
clusters with the butterfly core structure such as $\left[\mathrm{Fe}_{3} \mathrm{Mn}(\mathrm{CO})_{12}\left(\mu_{4}-\mathrm{E}\right)\right][\mathrm{PPN}](\mathrm{E}=\mathrm{O}$,

S),,$\underline{39}\left[\mathrm{Ru}_{3} \mathrm{Co}(\mathrm{CO})_{11}(\mathrm{PhCCPh})\right]^{-44}$ and $\left[\mathrm{CpCO}_{3} \mathrm{Fe}(\mathrm{CO})_{7}(\mu-\mathrm{CO})_{2}\left(\mu_{4}-\mathrm{C}=\mathrm{CH}_{2}\right)\right]$, ${ }^{45}$ the single metal atom $\mathrm{Mn}, \mathrm{Co}$, or Fe occupies a wingtip position as found in $\mathbf{3}, \mathbf{4}$, and $\mathbf{5}$. The interplanar angle of the butterfly is $152.7(1)^{\circ}$ in $\mathbf{3}$, $153.93(4)^{\circ}$ in 4 , and $153.5(1)^{\circ}$ in $\mathbf{5}$ and on their convex side, facially located, lies the $\mu_{3}-\mathrm{SN}_{2} \mathrm{C}_{4} \mathrm{H}_{5}$ moiety such that it is bonded to three metal atoms through the sulfur and nitrogen atom. In all structures the $\mu_{3^{-}}$ $\mathrm{SN}_{2} \mathrm{C}_{4} \mathrm{H}_{5}$ ligand bridges the hinge metal atoms through the sulfur, but coordinates to the wingtip group 7 metal ( $\mathrm{Mn}$ or $\mathrm{Re}$ ) through a nitrogen atomand all contain a noncrystallographic mirror plane of symmetry passing through the plane of the heterocyclic ring and also containing the wingtip metals of the butterfly.

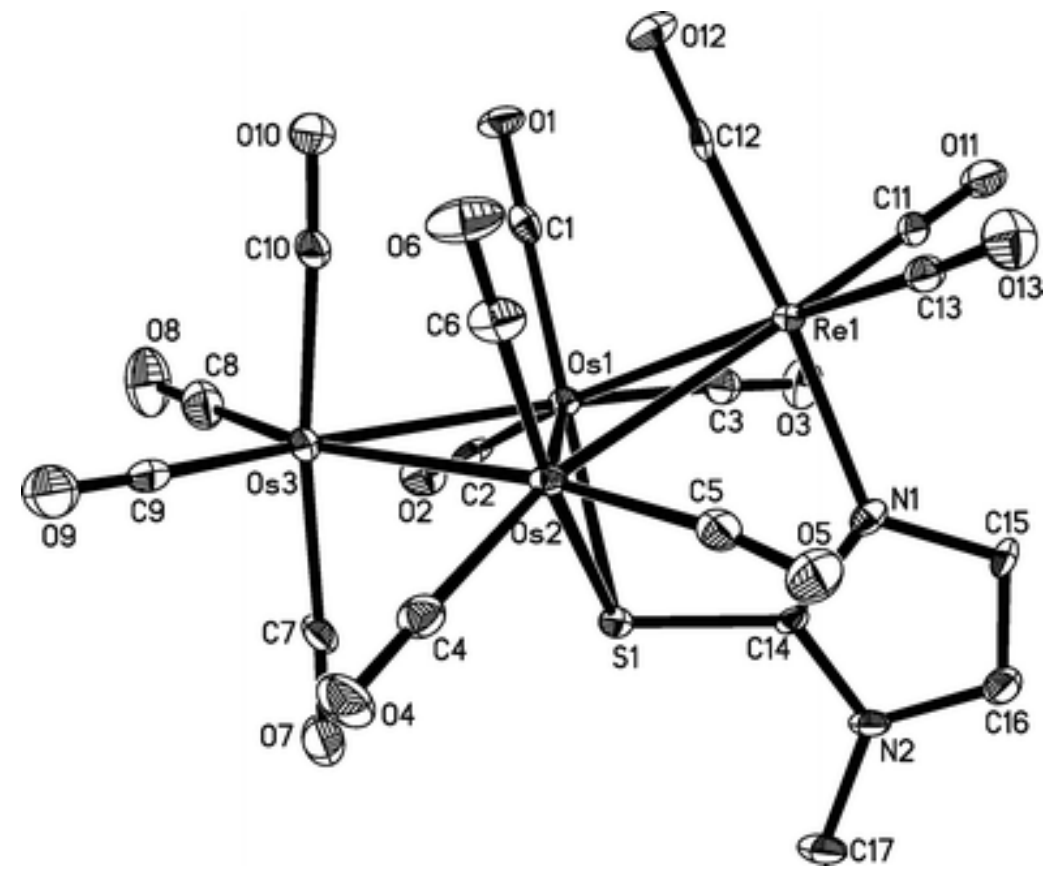

Fig. 1 ORTEP diagram of the molecular structure of $\left[\mathrm{Os}_{3} \mathrm{Re}(\mathrm{CO}){ }_{13}\left(\mu_{3}-\mathrm{SN}_{2} \mathrm{C}_{4} \mathrm{H}_{5}\right)\right](3)$, showing $50 \%$ probability thermal ellipsoids. Selected interatomic distances $(\AA)$ and angles $\left({ }^{\circ}\right)$ : Os(1)-Os(2) 2.7928(4), Os(1)-Os(3) 2.8638(4), Os(2)-Os(3) 2.8603(4), Os(1)-Re(1) 2.9466(4), Os(2)-Re(1) 2.9171(4), Os(1)-S(1) 2.424(2), Os(2)$\mathrm{S}(1)$ 2.425(2), Re(1)-N(1) 2.159(6), C(14)-S(1) 1.748(7), Os(2)-Os(1)-Os(3) 60.73(1), Os(2)-Os(1)-Re(1) 61.03(1), Os(3)-Os(1)-Re(1) 116.18(1), Os(1)-Os(2)-Re(1) 62.09(1), Os(1)-Os(2)-Os(3) 60.86(1), Os(3)-Os(2)$\operatorname{Re}(1)$ 117.25(1), Os(2)-Re(1)-Os(1) 56.88(9), Os(2)-Os(3)-Os(1) 58.40(1), Os(1)-S(1)-Os(2) 70.33(5). 


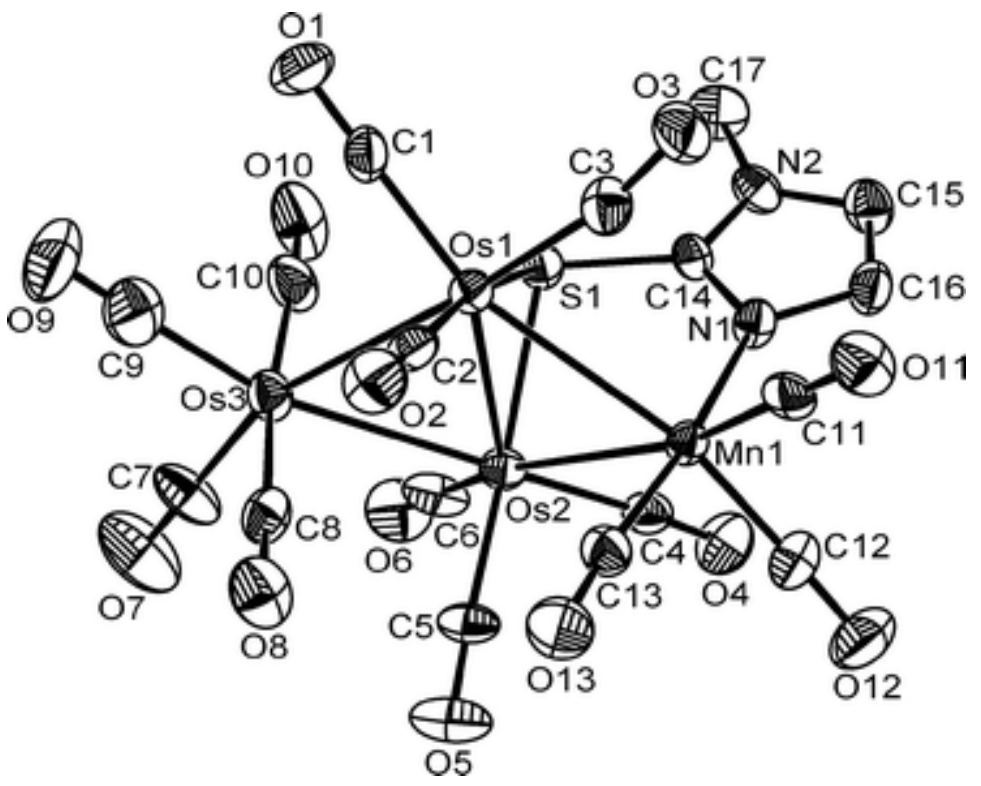

Fig. 2 ORTEP diagram of the molecular structure of $\left[\mathrm{Os}_{3} \mathrm{Mn}(\mathrm{CO})_{13}\left(\mu_{3}-\mathrm{SN}_{2} \mathrm{C}_{4} \mathrm{H}_{5}\right)\right](4)$, showing $50 \%$ probability thermal ellipsoids. Selected interatomic distances $(\AA ̊)$ and angles $\left({ }^{\circ}\right)$ : Os(1)-Os(2) 2.7978(6), Os(1)-Os(3) 2.8635(7), Os(2)-Os(3) 2.8635(6), Os(1)-Mn(1) 2.867(2), Os(2)-Mn(1) 2.893(2), Os(1)-S(1) 2.419(3), Os(2)$\mathrm{S}(1)$ 2.425(3), $\mathrm{Mn}(1)-\mathrm{N}(1)$ 2.026(9), C(14)-S(1) 1.76(1), Os(2)-Os(1)-Os(3) 60.76(2), Os(2)-Os(1)-Mn(1) 61.40(3), Os(3)-Os(1)-Mn(1) 117.03(3), Os(1)-Os(2)-Mn(1) 60.48(3), Os(1)-Os(2)-Os(3) 60.76(2), Os(3)Os(2)-Mn(1) 116.19(4), Os(2)-Mn(1)-Os(1) 58.13(3), Os(2)-Os(3)-Os(1) 58.49(2), Os(1)-S(1)-Os(2) 70.55(8).

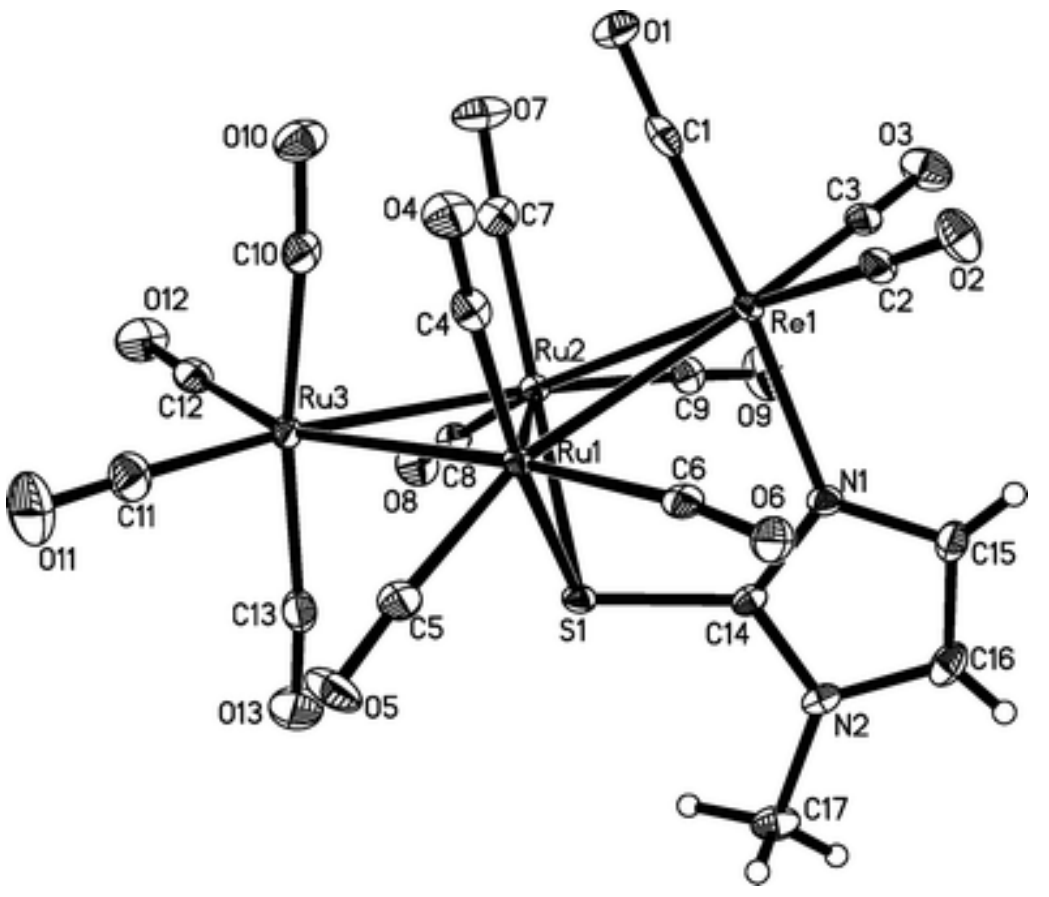

Fig. 3 ORTEP diagram of the molecular structure of $\left[\mathrm{Ru} u_{3} \operatorname{Re}(\mathrm{CO})_{13}\left(\mu_{3}-\mathrm{SN}_{2} \mathrm{C}_{4} \mathrm{H}_{5}\right)\right](5)$, showing $50 \%$ probability thermal ellipsoids. Selected interatomic distances $(\AA)$ and angles $\left({ }^{\circ}\right): \operatorname{Ru}(1)-\operatorname{Ru}(2) 2.7853(4), \operatorname{Ru}(1)-\operatorname{Ru}(3)$ 2.8318(4), $R u(2)-R u(3)$ 2.8327(4), $R u(1)-\operatorname{Re}(1)$ 2.9069(3), $R u(2)-R e(1)$ 2.9342(3), $R u(1)-S(1)$ 2.3926(9), $R u(2)-$ $\mathrm{S}(1)$ 2.3987(9), Re(1)-N(1) 2.177(3), C(14)-S(1) 1.757(4), Ru(2)-Ru(1)-Ru(3) 60.56(1), Ru(2)-Ru(1)-Re(1) 
62.015(9), Ru(3)-Ru(1)-Re(1) 117.24(1), Ru(1)-Ru(2)-Re(1) 61.029(8), Ru(1)-Ru(2)-Ru(3) 60.53(1), Ru(3)$\mathrm{Ru}(2)-\operatorname{Re}(1)$ 116.32(1), $R u(2)-\operatorname{Re}(1)-\operatorname{Ru}(1)$ 56.957(8), $R u(1)-\operatorname{Ru}(3)-\operatorname{Ru}(2)$ 58.906(9), $R u(1)-S(1)-\operatorname{Ru}(2)$ 71.09(3).
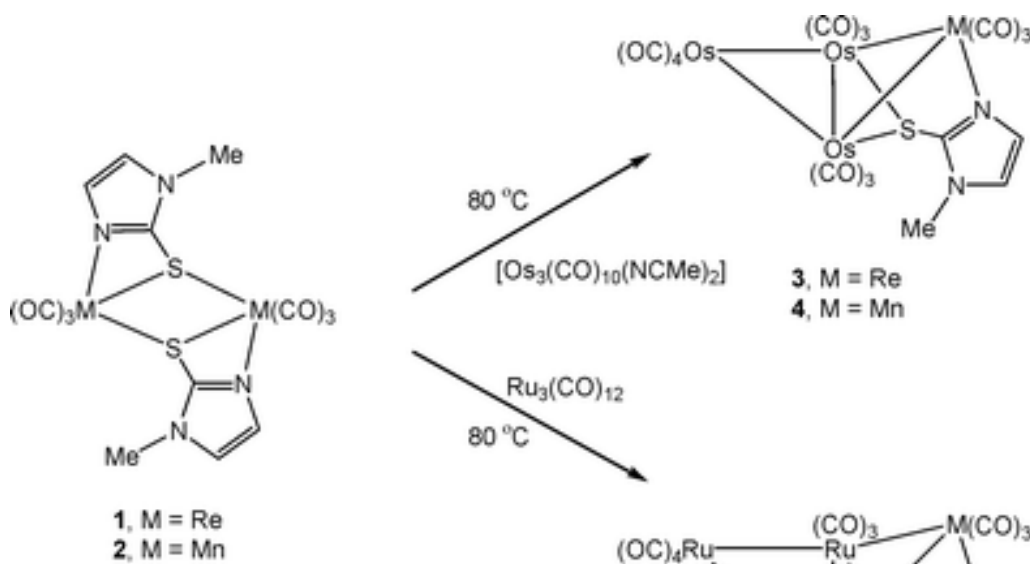

$2 M=M n$

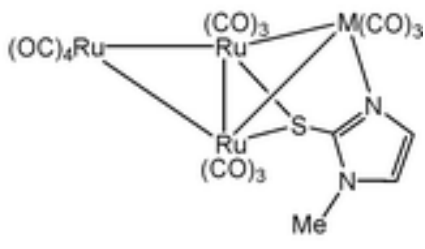

5, $M=\operatorname{Re}$

\section{Scheme 2}

All metal-metal distances in $\mathbf{3}, \mathbf{4}$, and $\mathbf{5}$ are different, but in the expected range for $\mathrm{M}-\mathrm{M}^{\prime}$ and $\mathrm{M}^{\prime}-\mathrm{M}^{\prime}(\mathrm{M}=$ $\mathrm{Mn}, \mathrm{Re} ; \mathrm{M}^{\prime}=\mathrm{Ru}, \mathrm{Os}$ ) single bonds. ${ }^{34,35,38-41,43,46}$ The hinge metal-metal distance is shorter than other metalmetal distances of the cluster, although the $\mathrm{M}(1)-\mathrm{S}(1)-\mathrm{M}(2)$ angle in all of them is acute $\left(70.33(5)^{\circ}\right.$ in 3;

70.55(8) in 4; 71.09(3) in 5), the strain can be alleviated by the lengthening of this edge. In the three clusters, the coordination of the thirteen carbonyl ligands is the same: three bonded with each of the hinge metal atoms (Ru or Os), three with the wingtip group 7 metal atom (Mn or Re) and four with the wingtip group 8 metal atom (Ru or Os). The $\mu_{3}-\mathrm{SN}_{2} \mathrm{C}_{4} \mathrm{H}_{5}$ ligand symmetrically bridges the hinge metal-metal bonds and these Os-S and Ru-S bond lengths are within the range reported for related compounds. $\frac{28 a, 47,48}{}$ The $\mathrm{Mn}-\mathrm{N}$ bond distance in 4(2.026(9) $\AA$ ) and the Re-N bond distances in $\mathbf{3}(2.159(6) \AA)$ and $\mathbf{5}$ (2.177(3) $\AA$ ) are quite similar to those observed in 2 (av. 2.054(9) $\AA$ ) and [ $\left.\operatorname{Re}_{2}(\mathrm{CO})_{6}(\mu-\mathrm{MepyS})_{2}\right]$ (av. 2.187(6) $\AA$ ). ${ }^{27,49}$ All other features of these clusters are within the expected range and with an electron count of 62 . Compounds $\mathbf{3}, \mathbf{4}$, and $\mathbf{5}$ are electronically saturated $\mathrm{M}_{4}$ butterfly clusters. Density functional theory (DFT) calculations of 5 confirm geometric and electronic features of this butterfly cluster, giving an interplanar angle of $155.4^{\circ}$. Selected bond distances and frontier orbitals for $\mathbf{5}$ are reported in the ESI. +

A similar reaction of 2 with $\mathrm{Ru}_{3}(\mathrm{CO})_{12}$ affords $\left[\mathrm{Ru}_{3} \mathrm{Mn}(\mathrm{CO})_{13}\left(\mu_{3}-\mathrm{SN}_{2} \mathrm{C}_{4} \mathrm{H}_{5}\right)\right](6)$ and the trimanganese complex $\left[\mathrm{Mn}_{3}(\mathrm{CO})_{10}(\mu-\mathrm{Cl})\left(\mu_{3}-\mathrm{SN}_{2} \mathrm{C}_{4} \mathrm{H}_{5}\right)_{2}\right](7)$ in 18 and $15 \%$ yields, respectively (Scheme 3$)$. As we could not obtain

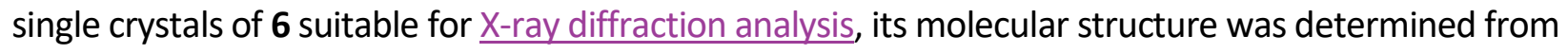
spectroscopic data and elemental analysis. The spectroscopic data of 6 indicate that it is a direct analog 
of $\mathbf{3}, \mathbf{4}$, and $\mathbf{5}$. The infrared spectrum in the carbonyl stretching region is very similar to that of $\mathbf{5}$ indicating structural similarity whereas the FAB mass spectrum shows the parent molecular ion at $\mathrm{m} / \mathrm{z} 837$ together with ions due to the sequential loss of thirteen carbonyl groups. Like $3-5$, the ${ }^{1} \mathrm{H}$ NMR spectrum consists of three resonances at $\delta 7.11,6.80$, and 3.60 with a relative intensity of 1:1:3 corresponding to the ring protons and the methyl protons of the heterocyclic ligand. To our knowledge complexes 3-6 are the first examples of butterfly mixed-metal organometallic clusters of group $7 / 8$ metals with a $\mu_{3-}$ heterocyclic ligand.

2

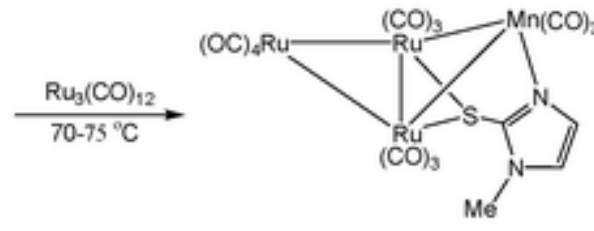

6

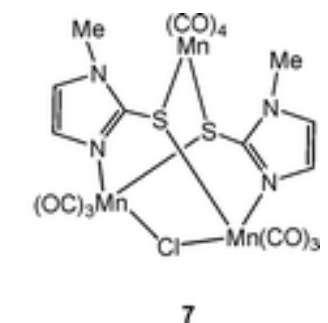

7

Scheme 3

An ORTEP diagram of the molecular structure of $\mathbf{7}$ is depicted in Fig. 4, and selected bond lengths and angles are listed in the caption. The molecule consists of a trinuclear framework of three manganese atoms with ten terminal carbonyl groups, two triply bridging 2-mercapto-1-methylimidazolate ligands and a bridging chloride ligand. One manganese atom $(\mathrm{Mn}(1))$ is bonded to four carbonyl groups while the other two manganese atoms bond with three carbonyl groups. Each $\mu_{3}-\mathrm{SN}_{2} \mathrm{C}_{4} \mathrm{H}_{5}$ ligand bridges two manganese atoms through the sulfur atom while coordinating with the third manganese atom through a nitrogen atom. The $\mu_{3}-\mathrm{SN}_{2} \mathrm{C}_{4} \mathrm{H}_{5}$ ligands are spatially oriented on opposite sides relative to the $\mathrm{Mn}_{3}$ plane and bridge the manganese atoms through the sulfur atom ( $\mathrm{Mn}(1)$ and $\mathrm{Mn}(2)$ or $\mathrm{Mn}(1)$ and $\mathrm{Mn}(2) \# 1)$ quite asymmetrically (Mn(1)-S(1) 2.3942(6), Mn(2)\#1-S(1) 2.4435(6), Mn(1)-S(1)\#1 2.3941(6), Mn(2)-S(1)\#1 2.4435(6) Å). The $\mathrm{Mn}-\mathrm{N}$ and the $\mathrm{Mn}-\mathrm{S}$ bond distances in 7 are close to those observed in $1 . \underline{27}$ The source of the chloride ligand was not identified in this study. We can only speculate that it probably came from chlorinated solvent during chromatographic separation or recrystallization. The chloride ligand symmetrically bridges ( $\mathrm{Mn}(2) \# 1-\mathrm{Cl}(1) 2.3631(5) \AA)$ the $\mathrm{Mn}(2)$ and $\mathrm{Mn}(2) \# 1$ atoms and the $\mathrm{Mn}-\mathrm{Cl}$ distance in $\mathbf{7}$ is somewhat shorter than those observed in $\left[\mathrm{Mn}(\mu-\mathrm{Cl})\left\{\mathrm{C}\left(\mathrm{SiMe}_{3}\right)_{2}\left(\mathrm{SiMe}_{2} \mathrm{NMe}_{2}\right)\right\}\right]_{2}(\mathrm{av}$. 2.4275(9) $\AA$ ) and $\left[\mathrm{Mn}(\mathrm{THF})(\mu-\mathrm{Cl})\left\{\mathrm{C}\left(\mathrm{SiMe}_{3}\right)_{2}\left(\mathrm{SiMe}_{2} \mathrm{OMe}_{2}\right)\right\}\right]_{2}$ (av. 2.488(9) $\AA$ ).. .0 The three $\mathrm{Mn} \cdots \mathrm{Mn}$ distances in 7 are very long ( $\mathrm{Mn}(1) \cdots \mathrm{Mn}(2) 4.169(1) \AA$, and $M n(2) \cdots M n(2) \# 13.997 \AA$ ) which clearly ruled out the presence of any $\mathrm{Mn}-\mathrm{Mn}$ bond. Assuming the 2-mercapto-1-methylimidazolate ligand serves as a 5-electron donor each manganese atom achieves an 18-electron configuration without any metal-metal bond. The infrared spectrum of $\mathbf{7}$ indicates the presence of only terminal carbonyl groups while the ${ }^{1} \mathrm{H}$ NMR spectrum shows three singlets at $\delta 3.99,6.99$, and 7.34 due to the methyl and ring protons of the heterocyclic ligand in a 3:1:1 ratio which is consistent with the solid state structure. To our knowledge there are no known examples of 54-electron trimanganese compounds, which are direct analogs of 7. Geometry 
optimization of $\mathbf{7}$ by DFT gave a highly symmetric structure, which is in good agreement with X-ray data. The computed $\mathrm{Mn}(2)-\mathrm{Mn}(2) \# 1$ distance is $4.156 \AA$, and both canonical and NBO ${ }^{51}$ population analyses confirm that no interaction is occurring between the two metal atoms. HOMO and LUMO orbitals for 7are reported in Fig. 5.

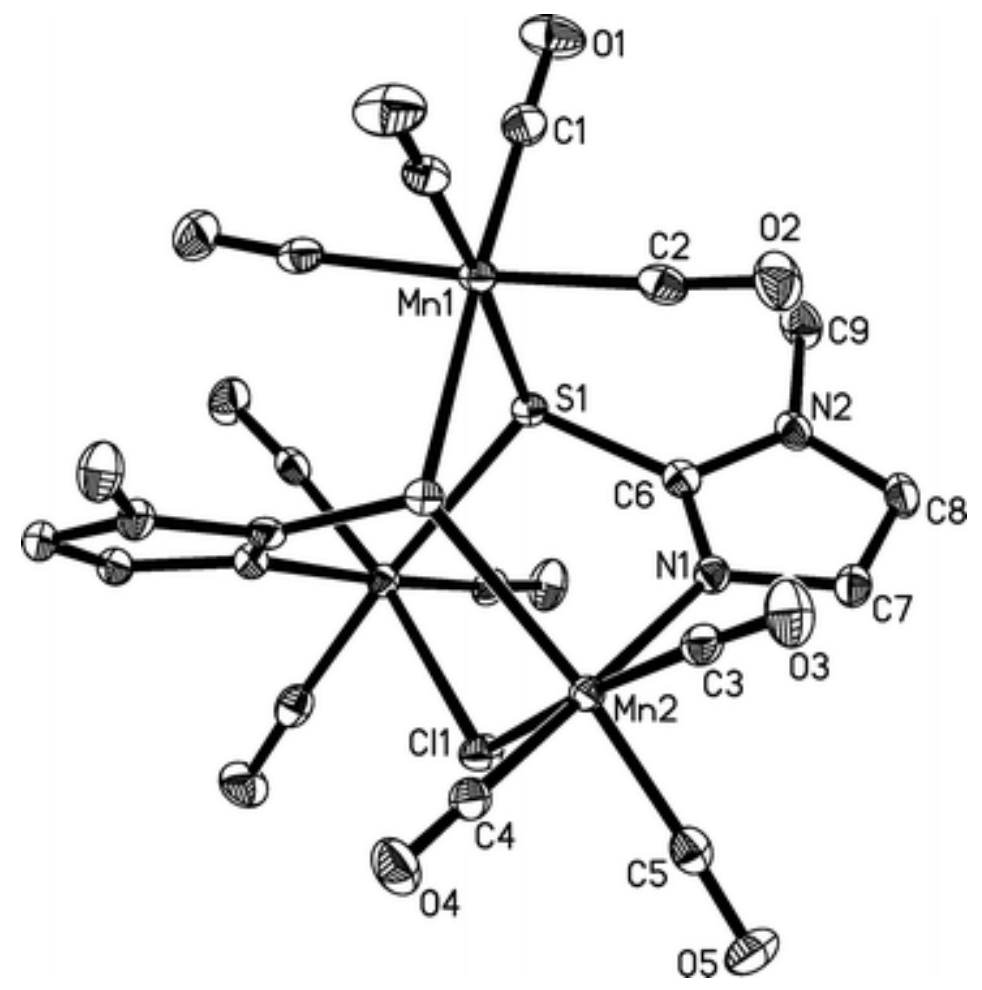

Fig. 4 ORTEP diagram of the molecular structure of $\left[\mathrm{Mn}_{3}(\mathrm{CO})_{10}(\mu-\mathrm{Cl})\left(\mu_{3}-\mathrm{SN}_{2} \mathrm{C}_{4} \mathrm{H}_{5}\right)_{2}\right](7)$, showing $50 \%$ probability thermal ellipsoids. Selected interatomic distances $(\AA ̊)$ and angles $\left({ }^{\circ}\right): M n(1)-S(1) 2.3942(6), M n(1)-S(1) \# 1$ 2.3941(6), Mn(2)-S(1)\#1 2.4435(6), Mn(2)\#1-S(1) 2.4435(6), Mn(2)-N(1) 2.058(2), Mn(2)\#1-Cl(1) 2.3631(5), $\mathrm{C}(6)-\mathrm{S}(1)$ 1.753(2), S(1)\#1-Mn(1)-S(1) 85.27(3), N(1)-Mn(2)-S(1)\#1 93.98(5), Cl(1)-Mn(2)-S(1)\#1 95.21(2), $\mathrm{Mn}(2) \# 1-\mathrm{Cl}(1)-\mathrm{Mn}(2) 115.52(3)$.

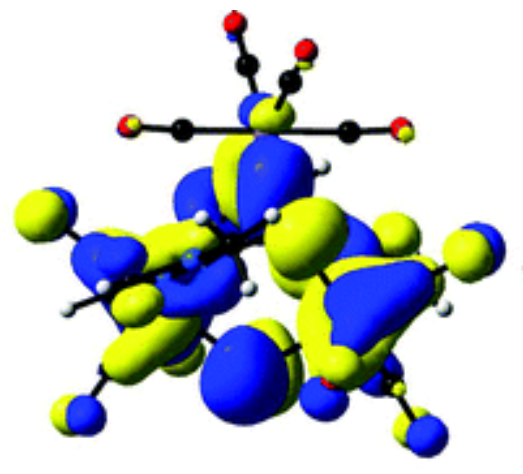

HOMO

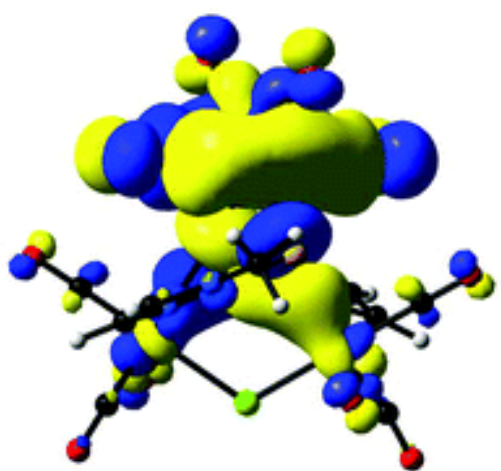

LUMO

Fig. 5 HOMO and LUMO orbitals for 7. 


\section{(b) Formation of di- and trinuclear rhenium complexes}

An unprecedented reaction took place when 1 is treated with $\mathrm{Fe}_{3}(\mathrm{CO})_{12}$. Recently, we reported that the reaction of 2 with $\mathrm{Fe}_{3}(\mathrm{CO})_{12}$ at $70-75{ }^{\circ} \mathrm{C}$ afforded the mixed Fe-Mn complex $\left[\mathrm{FeMn}_{2}(\mathrm{CO})\right)_{8}(\mu-\mathrm{CO})\left(\mu_{3^{-}}\right.$ $\left.\left.\mathrm{SN}_{2} \mathrm{C}_{4} \mathrm{H}_{5}\right)_{2}\right] ;$; 27 whereas, 1 under the same conditions reacts with $\mathrm{Fe}_{3}(\mathrm{CO})_{12}$ to give the tri- and dirhenium complexes $\left[\operatorname{Re}_{3}(\mathrm{CO})_{10}(\mu-\mathrm{H})\left(\mu_{3}-\mathrm{SN}_{2} \mathrm{C}_{4} \mathrm{H}_{5}\right)_{2}\right](8)$ and $\left[\mathrm{Re}_{2}(\mathrm{CO})_{6}\left(\mathrm{~N}_{2} \mathrm{C}_{4} \mathrm{H}_{5}\right)\left(\mu-\mathrm{SN}_{2} \mathrm{C}_{4} \mathrm{H}_{5}\right)_{2}\right](9)$ in 11 and $27 \%$ yields, respectively (Scheme 4$)$. No other bands were observed in TLC-plates. Heating $\mathbf{2}$ under the same conditions in the absence of $\mathrm{Fe}_{3}(\mathrm{CO})_{12}$ did not make any change. These rhenium complexes have been characterized by elemental analysis, $\underline{I R}$ and $\underline{{ }^{1} \mathrm{H} N M R}$ spectroscopic and mass spectroscopic data and single crystal X-ray diffraction analysis.

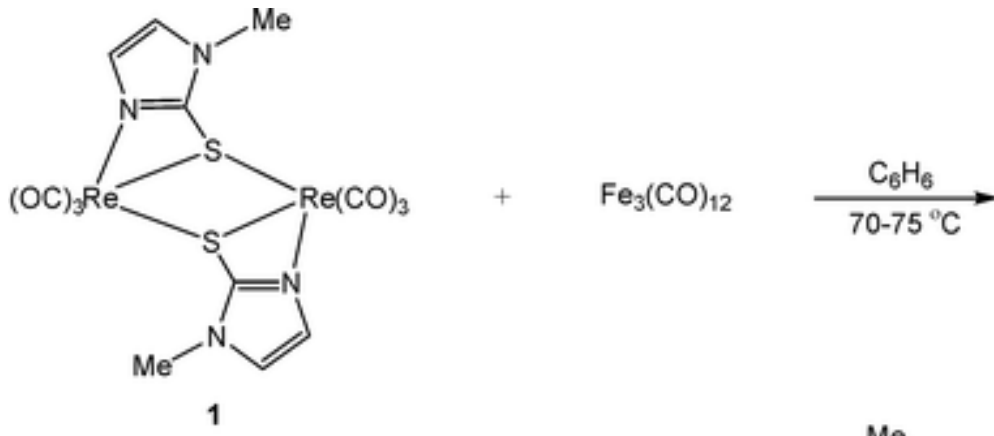

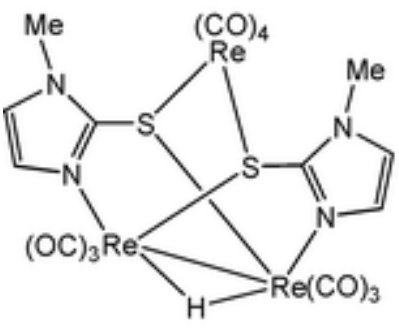

8

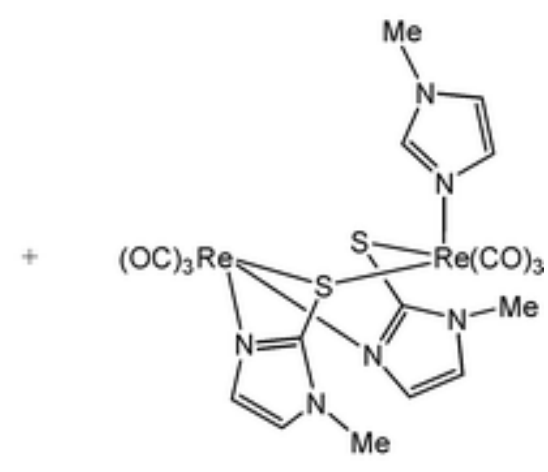

9

Scheme 4

An ORTEP drawing of the molecular structure of $\mathbf{8}$ is shown in Fig. 6 , and selected bond distances and angles are listed in the caption. The molecule contains a trimetallic core of three rhenium atoms with ten terminal carbonyl groups, two 2-mercapto-1-methylimidazolate ligands and a bridging hydride complete the coordination sphere of the complex. According to electron counting procedures, the complex should contain a Re-Re bond for each metal atom to achieve the 18-electron configuration. The structure is similar to that of 7 except that a bridging hydride and a metal-metal bond replace the bridging chloride ligand in 7.

The hydride is located in structural analysis and is found to span across the bonding metal-metal edge $(\operatorname{Re}(2)-\operatorname{Re}(2) \# 1)$. The Re-Re bond distance in 8 (3.3486(3) $\AA$ ) is considerably longer than those observed in $\left.\left[\operatorname{Re}_{3}(\mathrm{CO})_{8}(\mu-\mathrm{CO})(\mu-\mathrm{H})\left(\mu_{3}-\mathrm{SN}_{2} \mathrm{C}_{4} \mathrm{H}_{5}\right)_{2}\right)\right]($ av. $2.9964(13) \AA ̊),{ }^{27}\left[\operatorname{Re}_{2}(\mathrm{CO})_{7}(\mathrm{MeCN})(\mu-\mathrm{C} \equiv \mathrm{CPh})(\mu-\mathrm{H})\right]^{52}(3.0788(4) \AA)$ 
and the nonhydride bridging vector in $\left[\operatorname{Re}_{2}(\mathrm{CO})_{8}\left(\mu-\mathrm{SnPh}_{2}\right)\right](3.1902(4) \AA)^{53}$ while the average $\mathrm{Re}-\mathrm{N}$ and $\operatorname{Re}-\mathrm{S}$ bond distances in 8 (2.180(13) $\AA$ and 2.475(1) $\AA$ ) are within the range reported for related complexes. $\frac{27,49}{}$

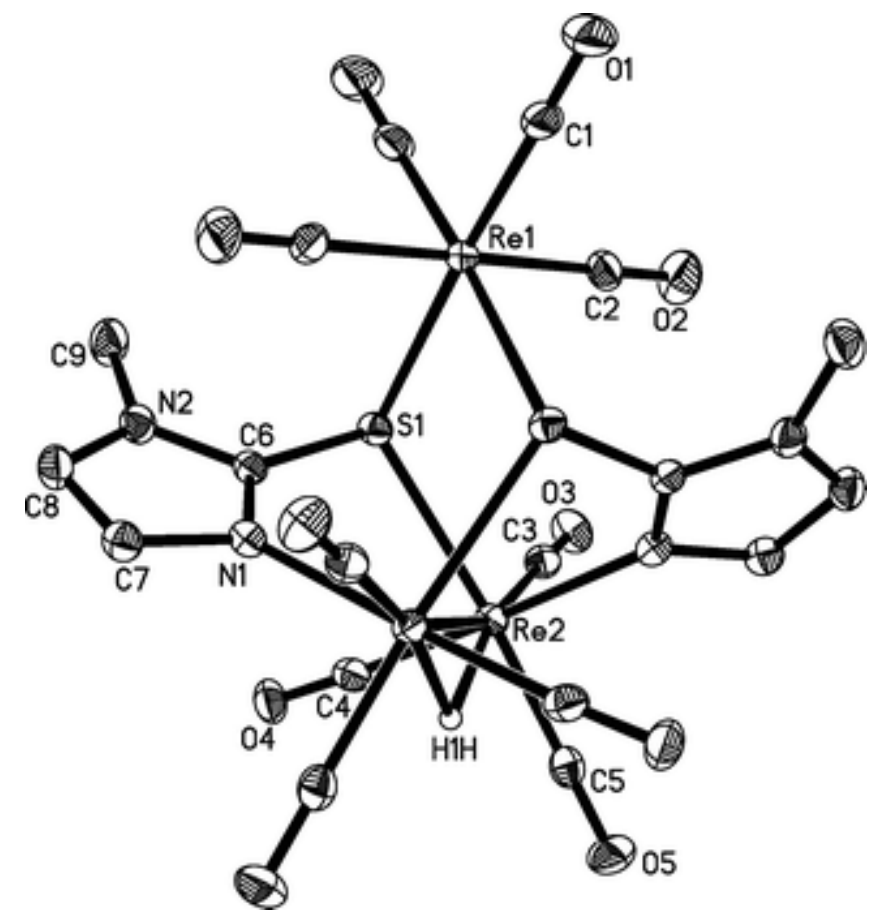

Fig. 6 ORTEP diagram of the molecular structure of $\left[\operatorname{Re}_{3}(\mathrm{CO})_{10}(\mu-\mathrm{H})\left(\mu_{3}-\mathrm{SN}_{2} \mathrm{C}_{4} \mathrm{H}_{5}\right)_{2}\right](8)$, showing $50 \%$ probability thermal ellipsoids. Selected interatomic distances $(\AA ̊)$ and angles $\left({ }^{\circ}\right): \operatorname{Re}(2)-\operatorname{Re}(2) \# 13.3486(3), \operatorname{Re}(1)-S(1) \# 1$ 2.511(1), $\operatorname{Re}(1)-\mathrm{S}(1)$ 2.511(1), $\operatorname{Re}(2)-\mathrm{N}(1) \# 1$ 2.179(4), $\operatorname{Re}(2)-\mathrm{S}(1)$ 2.550(1), $\operatorname{Re}(2)-\mathrm{H}(1 \mathrm{H})$ 1.97(5), C(6)-S(1) 1.751(4), Re(2)\#1-N(1) 2.179(4), S(1)\#1-Re(1)-S(1) 84.45(5), C(5)-Re(2)-Re(2)\#1 104.4(1), C(4)-Re(2)-Re(2)\#1 100.6(1), C(3)-Re(2)-Re(2)\#1 159.8(1), N(1)-Re(2)-Re(2)\#1 78.7(1), S(1)-Re(2)-Re(2)\#1 77.11(2), $\operatorname{Re}(2) \# 1-$ $\operatorname{Re}(2)-H(1 H) 32(2), \operatorname{Re}(1)-S(1)-\operatorname{Re}(2) 117.62(4)$.

DFT calculation provides a good description of the geometry and electronic structure of $\mathbf{8}$, confirming the presence of a metal-metal bond between $\operatorname{Re}(2)$ and $\operatorname{Re}(2) \# 1$ (see Fig. 6). The computed $\operatorname{Re}(2)-\operatorname{Re}(2) \# 1$ bond distance is $3.477 \AA$. As shown in Fig. 7, HOMO-3, HOMO-4 and HOMO-5 can account for such an interaction. HOMO and LUMO orbitals in $\mathbf{8}$ are similar to the frontier orbitals of $\mathbf{7}$ (Fig. 5 and 7 ). In both clusters the HOMO is delocalized over the three metal centers, while the LUMO is localized on the $\operatorname{Re}(1)$ center. In 7, however, the HOMO has anti-phase character between $\mathrm{Mn}(2)$ and $\mathrm{Cl}(1)$ and between $\mathrm{Mn}(2) \# 1$ and $\mathrm{Cl}(1)$, which can account for the long $\mathrm{Mn}(2)-\mathrm{Mn}(2) \# 1$ bond distance (4.156 ̊). Calculated $\mathrm{Mn}(2)-\mathrm{Mn}(1)$ and $\mathrm{Mn}(2) \# 1-\mathrm{Mn}(1)$ bond distances are both $4.316 \AA, \sim 0.21 \AA$ shorter than the $\operatorname{Re}(2)-\operatorname{Re}(1)$ and $\operatorname{Re}(2) \# 1-\operatorname{Re}(1)$ ones in $\mathbf{8}$. Compound $\mathbf{8}$ represents a rare example of a 52-electron trirhenium cluster containing a bridging hydride and two triply bridging heterocyclic ligands. The spectroscopic data of complex $\mathbf{8}$ are consistent with the solid-state structure being maintained in solution. In addition to the resonances for the protons of the heterocyclic ligands, the ${ }^{1} \mathrm{H}$ NMR spectrum shows a singlet at $\delta-9.41$ due to the bridging hydride ligand. The FAB mass spectrum exhibits the molecular ion at $m / z 1066$ and other ions due to the sequential loss of ten carbonyl groups. 

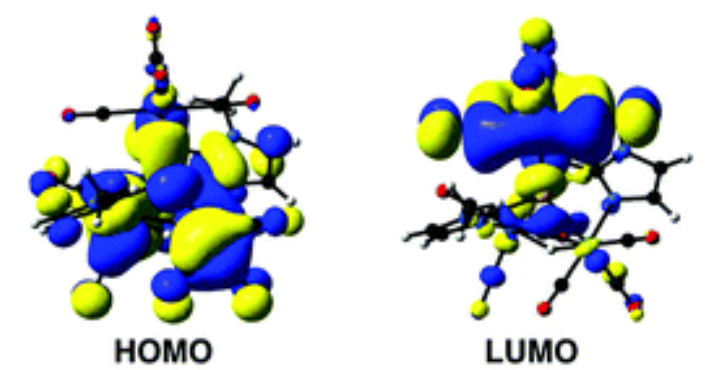

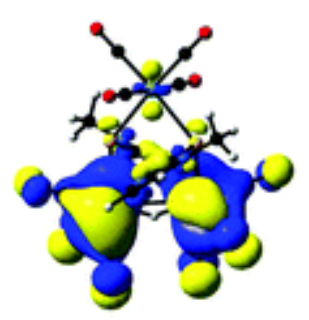

HOMO-3

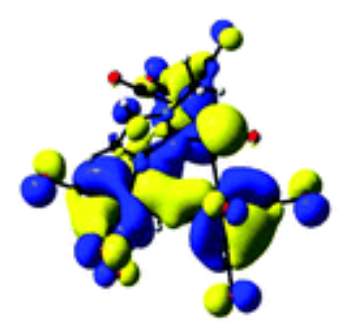

HOMO-4

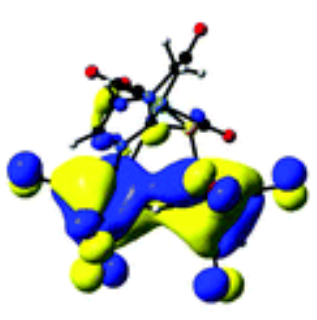

HOMO-5

Fig. 7 Selected molecular orbitals of 8 .

An ORTEP diagram of the molecular structure of 9 is depicted in Fig. 8, and selected bond distances and angles are listed in the caption. The molecule consists of a dinuclear framework of two rhenium atoms ligated by six terminal carbonyl groups, three of which are bonded to each of the two rhenium atoms, two bridging 2-mercapto-1-methylimidazolate ligands and a monocoordinated 1-methylimidazole ligand. The coordination modes of the bridging ligands are different: one bridges the rhenium atoms through the sulfur and a nitrogen atom whereas the other bridges the rhenium atoms through the sulfur atom while forming a four-membered chelate ring by coordinating through a nitrogen atom. The 1-methylimidazole is axially coordinated to $\operatorname{Re}(2)$. The salient feature of 9 reveals that one of the heterocyclic ligands has undergone $\mathrm{C}-\mathrm{S}$ bond cleavage upon coordinating to the metal framework, while the other two remain intact within the complex. The average Re-N and Re-S bond distances in 9 (2.186(3) $\AA$ and 2.545(1) $\AA$ ) are comparable to those of 8 and are also in the range found in the literature. $\frac{27,49}{}$ The Re $\cdots$ Re distance is very long (4.420(1) $\AA$ ) and clearly a nonbonding distance. The spectroscopic data of compound 9 are fully consistent with the solidstate structure. The ${ }^{1} \mathrm{H}$ NMR spectrum displays seven resonances at $\delta 3.65,3.77,6.59,6.82,6.89,7.29$ and 7.98 in 6:3:2:2:1:1:1 ratio. The resonances at $\delta 3.65,6.59$ and 6.82 are due to the protons of the bridging 2mercapto-1-methylimidazolate ligands and the rest of the resonances are due to the protonsof the 1 methylimidazole ligand. The FAB mass spectrum shows the parent molecular ion at $\mathrm{m} / \mathrm{z} 848$ together with fragmentation ions due to the successive loss of six carbonyl groups. 


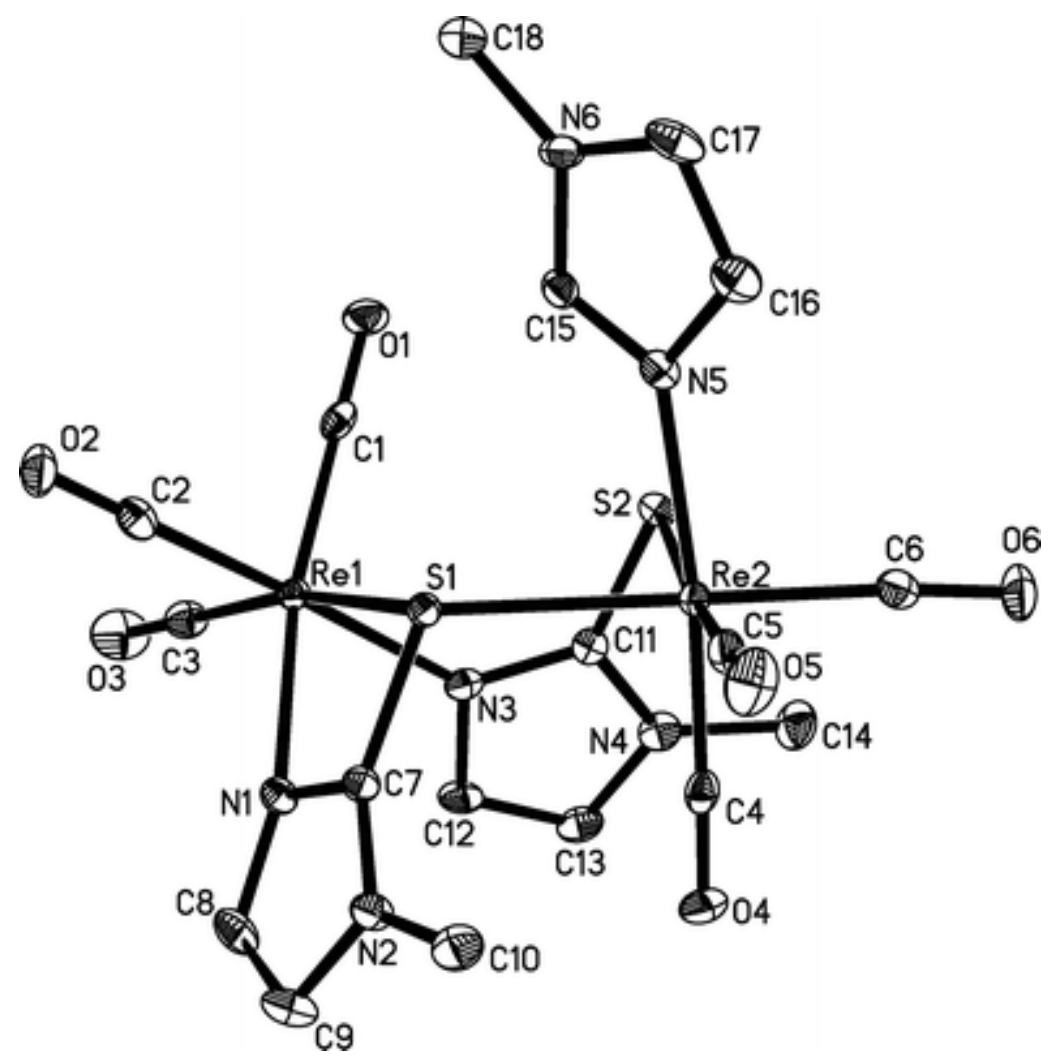

Fig. 8 ORTEP diagram of the molecular structure of $\left[\operatorname{Re}_{2}(\mathrm{CO})_{6}\left(\mathrm{~N}_{2} \mathrm{C}_{4} \mathrm{H}_{5}\right)\left(\mu-\mathrm{SN}_{2} \mathrm{C}_{4} \mathrm{H}_{5}\right)_{2}\right](9)$, showing $50 \%$ probability thermal ellipsoids. Selected interatomic distances $(\AA ̊)$ and angles $\left({ }^{\circ}\right)$ : $\operatorname{Re}(1)-N(1) 2.183(3), \operatorname{Re}(1)-N(3) 2.173(3)$, $\operatorname{Re}(2)-N(5)$ 2.203(3), $\operatorname{Re}(1)-S(1)$ 2.5873(9), $\operatorname{Re}(2)-S(1)$ 2.5245(9), $\operatorname{Re}(2)-S(2)$ 2.5222(9), C(7)-S(1) 1.752(4), $\mathrm{C}(11)-\mathrm{S}(2) 1.726(4), \mathrm{N}(3)-\operatorname{Re}(1)-\mathrm{N}(1)$ 81.6(1), N(3)-Re(1)-S(1) 88.25(8), N(1)-Re(1)-S(1) 65.68(8), N(5)-Re(2)$S(2) 82.33(8), N(5)-\operatorname{Re}(2)-S(1)$ 82.85(8), S(2)-Re(2)-S(1) 86.78(3), $\operatorname{Re}(2)-S(1)-\operatorname{Re}(1)$ 119.70(3), C(4)-Re(2)-N(5) 173.6(1), C(6)-Re(2)-S(1) 178.4(1), C(5)-Re(2)-S(2) 173.1(1).

\section{Conclusions}

This report demonstrates that the dinuclear complexes $\mathbf{1}$ and $\mathbf{2}$ are versatile synthons for the synthesis of group 7/8 tetranuclear mixed-metal clusters3-6 containing 2-mercapto-1-methylimidazolate ligand, all of which possess 62-electron butterfly skeletal arrangement with the group 7 metal ( $\mathrm{Mn}$ or $\mathrm{Re}$ ) in a wingtip position. In these reactions, the usefulness of $\mathbf{1}$ and $\mathbf{2}$ to open up a novel synthetic strategy to furnish a new butterfly cluster is remarkable. Most probably, the facile $\mathrm{M}-\mathrm{S}$ bond cleavage in $\mathbf{1}$ and $\mathbf{2}$ generates the $\left[\mathrm{M}(\mathrm{CO})_{3}\left(\mathrm{SN}_{2} \mathrm{C}_{4} \mathrm{H}_{5}\right)\right](\mathrm{M}=\mathrm{Mn}, \mathrm{Re})$ species in the reaction mixture which reacts with $\left[\mathrm{Os}_{3}(\mathrm{CO})_{10}(\mathrm{NCMe})_{2}\right]$ and $\mathrm{Ru}_{3}(\mathrm{CO})_{12}$ to form these butterfly clusters. The highly symmetric structure of $\mathbf{7}$ is consistent with DFT calculations. The mechanism of formation of 7 remains obscure, as attempts to obtain $\mathbf{7}$ by the reaction of 2 with $\mathrm{Mn}_{2}(\mathrm{CO})_{10}$ or $\left[\mathrm{Mn}_{2}(\mathrm{CO})_{8}(\mathrm{NCMe})_{2}\right]$ in refluxing $\mathrm{CH}_{2} \mathrm{Cl}_{2}$ or in benzene at $70-75^{\circ} \mathrm{C}$, by heating 7 in benzene at $70-75^{\circ} \mathrm{C}$ without $\mathrm{Ru}_{3}(\mathrm{CO})_{12}$ are, however, unsuccesful. In contrast to the reaction of 2 with $\mathrm{Fe}_{3}(\mathrm{CO})_{12}$ which afforded the mixed Mn-Fe complex $\left[\mathrm{FeMn} 2(\mathrm{CO})_{8}(\mu-\mathrm{CO})\left(\mu_{3}-\mathrm{SN}_{2} \mathrm{C}_{4} \mathrm{H}_{5}\right)_{2}\right], \underline{27}$ the reaction of 1 with $\mathrm{Fe}_{3}(\mathrm{CO})_{12}$ did not provide mixed Re-Fe complexes, but led to the formation of the trirhenium complex 8 and the dirhenium complex 9 which can not be obtained from the direct reaction 
between $\left[\operatorname{Re}_{2}(\mathrm{CO})_{8}(\mathrm{NCMe})_{2}\right]$ and 2-mercapto-1-methylimidazole. ${ }^{27}$ Like 7, compound 8 also has a highly symmetric structure and to our knowledge 8 possesses the longest Re-Re bond (3.3486(3) $\AA$ ) which is in good agreement with DFT calculations.

\section{Experimental}

All reactions were performed under a nitrogen atmosphere using standard Schlenk techniques unless otherwise stated. Reagent-grade solventswere dried by standard procedures and were distilled from appropriate drying agents prior to use. Infrared spectra were recorded on a Shimadzu FTIR 8101 spectrophotometer. NMR spectra were recorded on a Bruker DPX 400 instrument. Mass spectra were recorded on a Varian Mat 312mass spectrometer. The metal carbonyl compounds $\left(\mathrm{Os}_{3}(\mathrm{CO})_{12}, \mathrm{Ru}_{3}(\mathrm{CO})_{12}\right.$, $\mathrm{Fe}_{3}(\mathrm{CO})_{12}, \mathrm{Re}_{2}(\mathrm{CO})_{10}$, and $\left.\mathrm{Mn}_{2}(\mathrm{CO})_{10}\right)$ were purchased from Strem Chemical Inc. and used without further purification. 2-Mercapto-1-methylimidazole was purchased from Aldrich and used as received. The compounds $\left[\mathrm{Os}_{3}(\mathrm{CO})_{10}(\mathrm{NCMe})_{2}\right], \underline{54}\left[\operatorname{Re}_{2}(\mathrm{CO})_{8}(\mathrm{NCMe})_{2}\right], \underline{55}\left[\operatorname{Re}_{2}(\mathrm{CO})_{6}\left(\mu-\mathrm{SN}_{2} \mathrm{C}_{4} \mathrm{H}_{5}\right)_{2}\right] \stackrel{27}{(1)}$, and $\left[\mathrm{Mn}_{2}(\mathrm{CO})_{6}(\mu-\right.$ $\left.\left.\mathrm{SN}_{2} \mathrm{C}_{4} \mathrm{H}_{5}\right)_{2}\right]^{27}$ (2) were prepared according to the published procedures.

Reaction of $\left[\operatorname{Re}_{2}(\mathrm{CO})_{6}\left(\mu-\mathrm{SN}_{2} \mathrm{C}_{4} \mathrm{H}_{5}\right)_{2}\right](1)$ with $\left[\mathrm{Os}_{3}(\mathrm{CO})_{10}(\mathrm{NCMe})_{2}\right]$

A solution of $\left[\mathrm{Os}_{3}(\mathrm{CO})_{10}(\mathrm{NCMe})_{2}\right](125 \mathrm{mg}, 0.134 \mathrm{mmol})$ and $\left[\mathrm{Re}_{2}(\mathrm{CO})_{6}\left(\mu-\mathrm{SN}_{2} \mathrm{C}_{4} \mathrm{H}_{5}\right)_{2}\right](\mathbf{1})(80 \mathrm{mg}, 0.104 \mathrm{mmol})$ in benzene $(100 \mathrm{~mL})$ was heated to reflux for $1 \mathrm{~h}$ during which time the color changed from yellow to red. The solvent was removed under reduced pressure, and the residue chromatographed by $\underline{\text { TLC }}$ on silica gel. Elution with hexane/acetone $(4: 1, \mathrm{v} / \mathrm{v})$ developed two bands. The second band afforded $\left[\mathrm{Os}_{3} \mathrm{Re}(\mathrm{CO})_{13}\left(\mu_{3}-\mathrm{SN}_{2} \mathrm{C}_{4} \mathrm{H}_{5}\right)\right.$ ] (3) (100 mg, 60\%) as red crystals from $\mathrm{CH}_{2} \mathrm{Cl}_{2} /$ hexane at $4{ }^{\circ} \mathrm{C}$. The first band gave too little product for complete characterization. Spectral data for 3: Anal. Calcd for $\mathrm{C}_{17} \mathrm{H}_{5} \mathrm{~N}_{2} \mathrm{O}_{13} \mathrm{Os} 3 \mathrm{ReS} \mathrm{C}$, 16.54; $\mathrm{H}, 0.41 ; \mathrm{N}, 2.27$. Found: C, 16.69; $\mathrm{H}, 0.43 ; \mathrm{N}, 2.35 \%$. IR $\left(v_{\mathrm{CO}}, \mathrm{CH}_{2} \mathrm{Cl}_{2}\right): 2108(\mathrm{~m}), 2062$ (w), 2043 (vs),

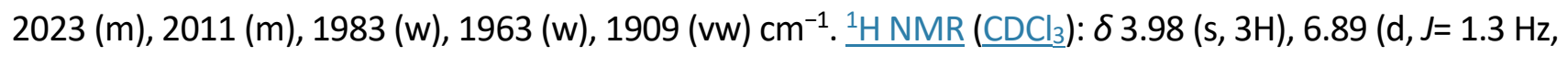
$1 \mathrm{H}), 7.57(\mathrm{~d}, J=1.3 \mathrm{~Hz}, 1 \mathrm{H})$.

\section{Reaction of $\left[\mathrm{Mn}_{2}(\mathrm{CO})_{6}\left(\mu-\mathrm{SN}_{2} \mathrm{C}_{4} \mathrm{H}_{5}\right)_{2}\right](2)$ with $\left[\mathrm{Os}_{3}(\mathrm{CO})_{10}(\mathrm{NCMe})_{2}\right]$}

A similar reaction to that above of $\left[\mathrm{Os}_{3}(\mathrm{CO})_{10}(\mathrm{NCMe})_{2}\right](225 \mathrm{mg}, 0.241 \mathrm{mmol})$ and $2(60 \mathrm{mg}, 0.119 \mathrm{mmol})$ followed by similar chromatographic separation afforded $\left[\mathrm{Os}_{3} \mathrm{Mn}(\mathrm{CO})_{13}\left(\mu_{3}-\mathrm{SN}_{2} \mathrm{C}_{4} \mathrm{H}_{5}\right)\right](4)$ as red crystals $(236$ $\mathrm{mg}, 88 \%$ ) after recrystallization from hexane $/ \mathrm{CH}_{2} \mathrm{Cl}_{2}$ at $4{ }^{\circ} \mathrm{C}$. Spectral data for 4 : Anal. Calcd for $\mathrm{C}_{17} \mathrm{H}_{5} \mathrm{MnN}_{2} \mathrm{O}_{13} \mathrm{Os} 3 \mathrm{~S}: \mathrm{C}, 18.51 ; \mathrm{H}, 0.46 ; \mathrm{N}, 2.54$. Found: $\mathrm{C}, 18.62 ; \mathrm{H}, 0.42 ; \mathrm{N}, 2.51 \%$. IR $\left(v_{\mathrm{co}}, \mathrm{CH}_{2} \mathrm{Cl}_{2}\right): 2106(\mathrm{~m})$, 2069 (vw), 2040 (vs), 2021 (vw), 2002 (s), 1961 (w), 1917 (w) 1869 (vw) cm ${ }^{-1} . \underline{{ }^{1} \mathrm{H} \mathrm{NMR}}$ ( $\left.\mathrm{CDCl}_{3}\right): \delta 3.97$ (s, 3H), $7.06(\mathrm{~s}, 1 \mathrm{H}), 8.04(\mathrm{~s}, 1 \mathrm{H}) \cdot \underline{\mathrm{MS}}: \mathrm{m} / \mathrm{z} 1102\left(\mathrm{M}^{+}\right)$.

\section{Reaction of 1 with $\mathrm{Ru}_{3}(\mathrm{CO})_{12}$}

To a benzene solution $(50 \mathrm{~mL})$ of $\mathrm{Ru}_{3}(\mathrm{CO})_{12}(86 \mathrm{mg}, 0.134 \mathrm{mmol})$ was added 1 (100 mg, $\left.0.130 \mathrm{mmol}\right)$ and the mixture was heated to reflux for $45 \mathrm{~min}$. The solvent was removed under vacuum, and the residue was taken up in $\mathrm{CH}_{2} \mathrm{Cl}_{2}$ and applied to silica gel TLC plates. Elution withhexane/acetone $(7: 3, \mathrm{v} / \mathrm{v})$ gave one major and several minor bands. The major band afforded $\left[\operatorname{ReRu}_{3}(\mathrm{CO})_{13}\left(\mu_{3}-\mathrm{SN}_{2} \mathrm{C}_{4} \mathrm{H}_{5}\right)\right](5)$ as deep red crystals (31 $\mathrm{mg}, 24 \%$ ) from hexane $/ \mathrm{CH}_{2} \mathrm{Cl}_{2}$ at $4{ }^{\circ} \mathrm{C}$ while the content of the minor bands was too small for complete 
characterization. Spectral data for 5: Anal. Calcd for $\mathrm{C}_{17} \mathrm{H}_{5} \mathrm{~N}_{2} \mathrm{O}_{13} R e R u_{3} \mathrm{~S}: \mathrm{C}, 21.12 ; \mathrm{H}, 0.52 ; \mathrm{N}, 2.90$. Found: C, 21.68; H, 0.49; N, 2.93\%. IR $\left(v_{\mathrm{CO}}, \mathrm{CH}_{2} \mathrm{Cl}_{2}\right): 2100(\mathrm{~m}), 2035$ (s), $2002(\mathrm{~s}), 1952(\mathrm{~m}), 1911(\mathrm{~m}), 1894(\mathrm{~m}), \mathrm{cm}^{-1} . \underline{{ }^{1} \mathrm{H}}$ $\underline{\mathrm{NMR}}(\underline{\mathrm{CDCl}}): \delta 4.07(\mathrm{~s}, 3 \mathrm{H}), 6.97(\mathrm{~d}, J=1.3 \mathrm{~Hz}, 1 \mathrm{H}), 7.46(\mathrm{~d}, J=1.3 \mathrm{~Hz}, 1 \mathrm{H})$.

\section{Reaction of 2 with $\mathrm{Ru}_{3}(\mathrm{CO})_{12}$}

A mixture of $\mathrm{Ru}_{3}(\mathrm{CO})_{12}(126 \mathrm{mg}, 0.197 \mathrm{mmol})$ and 2 (100 mg, $\left.0.198 \mathrm{mmol}\right)$ in benzene was heated at 70-75 ${ }^{\circ} \mathrm{C}$ for $1 \mathrm{~h}$. After removal of thesolvent under reduced pressure, the residue was chromatographed by $\underline{\mathrm{TLC}}$ on silica gel. Elution with hexane/ $\mathrm{CH}_{2} \mathrm{Cl}_{2}(7: 3 \mathrm{v} / \mathrm{v})$ developed three bands. The faster moving band gave unreacted $\mathrm{Ru}_{3}(\mathrm{CO})_{12}$ (trace), while the second and third bands afforded $\left[\mathrm{Mn}_{3}(\mathrm{CO})_{10}(\mu-\mathrm{Cl})\left(\mu_{3}-\mathrm{SN}_{2} \mathrm{C}_{4} \mathrm{H}_{5}\right)_{2}\right]$ (7) as orange crystals (18 mg, 15\%) and [ $\left.\mathrm{Ru}_{3} \mathrm{Mn}(\mathrm{CO})_{13}\left(\mu_{3}-\mathrm{SN}_{2} \mathrm{C}_{4} \mathrm{H}_{5}\right)\right](6)$ as red crystals $(30 \mathrm{mg}, 18 \%)$, respectively, from $\mathrm{CH}_{2} \mathrm{Cl}_{2} /$ hexane at $4{ }^{\circ} \mathrm{C}$. Spectral data for 6: Anal. Calcd for $\mathrm{C}_{17} \mathrm{H}_{5} \mathrm{MnN}_{2} \mathrm{O}_{13} \mathrm{Ru}_{3} \mathrm{~S}$ : C, 24.40; $\mathrm{H}$, 0.60; N, 3.35. Found: C, 24.51; H, 0.64; N, 3.39\%. $\underline{\mathrm{R}}\left(v_{\mathrm{CO}}, \mathrm{CH}_{2} \mathrm{Cl}_{2}\right)$ : 2099 (m), 2075 (w), 2044 (m), 2034 (s),

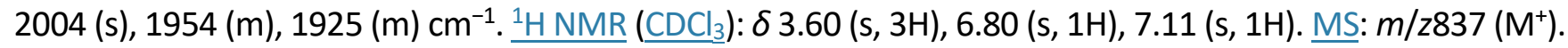
Spectral data for 7: Anal. Calcd for $\mathrm{C}_{18} \mathrm{H}_{10} \mathrm{ClMn}_{3} \mathrm{~N}_{4} \mathrm{O}_{10} \mathrm{~S}_{2}$ : C, 34.78; $\mathrm{H}, 1.61 ; \mathrm{N}, 9.02$. Found: $\mathrm{C}, 34.92 ; \mathrm{H}, 1.70 ; \mathrm{N}$, 9.38\%. IR ( $v_{\mathrm{co}}, \mathrm{CH}_{2} \mathrm{Cl}_{2}$ ): $2088(\mathrm{~m}), 2035(\mathrm{~m}), 2025$ (vs), 2007 (s), $1967(\mathrm{~m}), 1943(\mathrm{~s}), 1928(\mathrm{~s}) \mathrm{cm}^{-1} .{ }^{1} \mathrm{H}$ $\underline{\mathrm{NMR}}\left(\underline{\mathrm{CDCl}_{3}}\right): \delta 3.99(\mathrm{~s}, 3 \mathrm{H}), 6.99(\mathrm{~s}, 1 \mathrm{H}), 7.34(\mathrm{~s}, 1 \mathrm{H})$.

\section{Reaction of 1 with $\mathrm{Fe}_{3}(\mathrm{CO})_{12}$}

A mixture of $\mathrm{Fe}_{3}(\mathrm{CO})_{12}(200 \mathrm{mg}, 0.396 \mathrm{mmol})$ and $1(152 \mathrm{mg}, 0.198 \mathrm{mmol})$ was heated at $70-75^{\circ} \mathrm{C}$ for $2 \mathrm{~h}$. The solvent was removed under vacuum, and the residue was chromatographed by $\underline{\text { TLC }}$ on silica gel. Elution with hexane/acetone $(7: 3, \mathrm{v} / \mathrm{v})$ gave three bands. The first band was unreacted $\mathrm{Fe}_{3}(\mathrm{CO})_{12}$. The second and third bands gave $\left[\mathrm{Re}_{3}(\mathrm{CO})_{10}(\mu-\mathrm{H})\left(\mu_{3}-\mathrm{SN}_{2} \mathrm{C}_{4} \mathrm{H}_{5}\right)_{2}\right](8)$ as white crystals $(15 \mathrm{mg}, 11 \%)$ and $\left[\operatorname{Re}_{2}(\mathrm{CO})_{6}\left(\mathrm{~N}_{2} \mathrm{C}_{4} \mathrm{H}_{5}\right)\left(\mu-\mathrm{SN}_{2} \mathrm{C}_{4} \mathrm{H}_{5}\right)_{2}\right](9)$ as colorless crystals (45 mg, 27\%) after recrystallization from hexane $/ \mathrm{CH}_{2} \mathrm{Cl}_{2}$ at $4{ }^{\circ} \mathrm{C}$. Spectral data for 8: Anal. Calcd for $\mathrm{C}_{18} \mathrm{H}_{11} \mathrm{~N}_{4} \mathrm{O}_{10} \mathrm{Re}_{3} \mathrm{~S}_{2}$ : C, 20.28; H, 1.04; N, 5.26. Found: C, 20.55; H, 1.09; N, 5.31\%. IR ( $\left.v_{\mathrm{CO}}, \mathrm{CH}_{2} \mathrm{Cl}_{2}\right): 2104(\mathrm{w}), 2034(\mathrm{~m}), 2020$ (s), 2010 (m), $1999(\mathrm{~m}), 1956(\mathrm{~m}), 1922$ (s) cm $\left.{ }^{-1} .{ }^{1} \mathrm{H} \mathrm{NMR}_{\left(\mathrm{CDCl}_{3}\right.}\right): \delta 3.93(\mathrm{~s}, 3 \mathrm{H}), 6.71(\mathrm{~d}, J=1.3 \mathrm{~Hz}, 1 \mathrm{H}), 7.15$ (d, J=1.3 $\mathrm{Hz}, 1 \mathrm{H}),-9.41(\mathrm{~s}, 1 \mathrm{H}) . \mathrm{MS}: \mathrm{m} / \mathrm{z} 1066\left(\mathrm{M}^{+}\right)$. Spectral data for 9: Anal. Calcd for $\mathrm{C}_{18} \mathrm{H}_{16} \mathrm{~N}_{6} \mathrm{O}_{6} \mathrm{Re}_{2} \mathrm{~S}_{2}: \mathrm{C}, 25.47 ; \mathrm{H}$, 1.90; N, 9.90. Found: C, 25.63; H, 1.96; N, 9.94\%. IR ( $\left.v_{\mathrm{co}}, \mathrm{CH}_{2} \mathrm{Cl}_{2}\right): 2011$ (vs), 1908 (vs, br) cm ${ }^{-1} . \underline{{ }^{1} \mathrm{H}}$ NMR ( $\left.\underline{\mathrm{CDCl}_{3}}\right): \delta 3.65(\mathrm{~s}, 6 \mathrm{H}), 3.77(\mathrm{~s}, 3 \mathrm{H}), 6.59(\mathrm{~s}, 2 \mathrm{H}), 6.82(\mathrm{~s}, 2 \mathrm{H}), 6.89(\mathrm{~s}, 1 \mathrm{H}), 7.29(\mathrm{~s}, 1 \mathrm{H}), 7.98(\mathrm{~s}$, 1H). $\underline{\mathrm{MS}}: \mathrm{m} / \mathrm{z} 848\left(\mathrm{M}^{+}\right)$.

\section{X-Ray structure determinations}

Single crystals were mounted on fibres and diffraction data collected at low temperature (see Table 1) on Bruker AXS SMART APEX2 CCD (for compounds 3, 5, 7, 8 and 9) and Nonius KappaCCD (for compound 4) diffractometers using Mo and $\mathrm{Cu} K \alpha$ radiation $(\lambda=0.71073,1.54178 \AA$ ). Data collection, indexing and initial cell refinements were all done using SMART $\underline{56}$ (for compounds $\mathbf{3}, \mathbf{5}, \mathbf{7}, \mathbf{8}$ and $\mathbf{9}$ ) and DENZO and COLLECT 57 (for compound 4) softwares. Data reduction was accomplished with SAINT $\underline{58}$ and DENZO and COLLECT 57 (for compound 4) softwares and the SADABS $\underline{59}$ and SORTAV $\underline{60}$ programs were used to apply empirical absorption corrections. The structures were solved by direct methods $\underline{61}$ and refined by full matrix least-squares. $\underline{\underline{62}}$ All non-hydrogen atoms were refined anisotropically and hydrogen atoms were 
included using a riding model. Scattering factors were taken from International Tables for $\underline{X-r a y}$ Crystallography. $\cdot \underline{63}$ Additional details of data collection and structure refinement are given in Table 1.

Table 1 Crystallographic data and structure refinement for 3-5 and 7-9

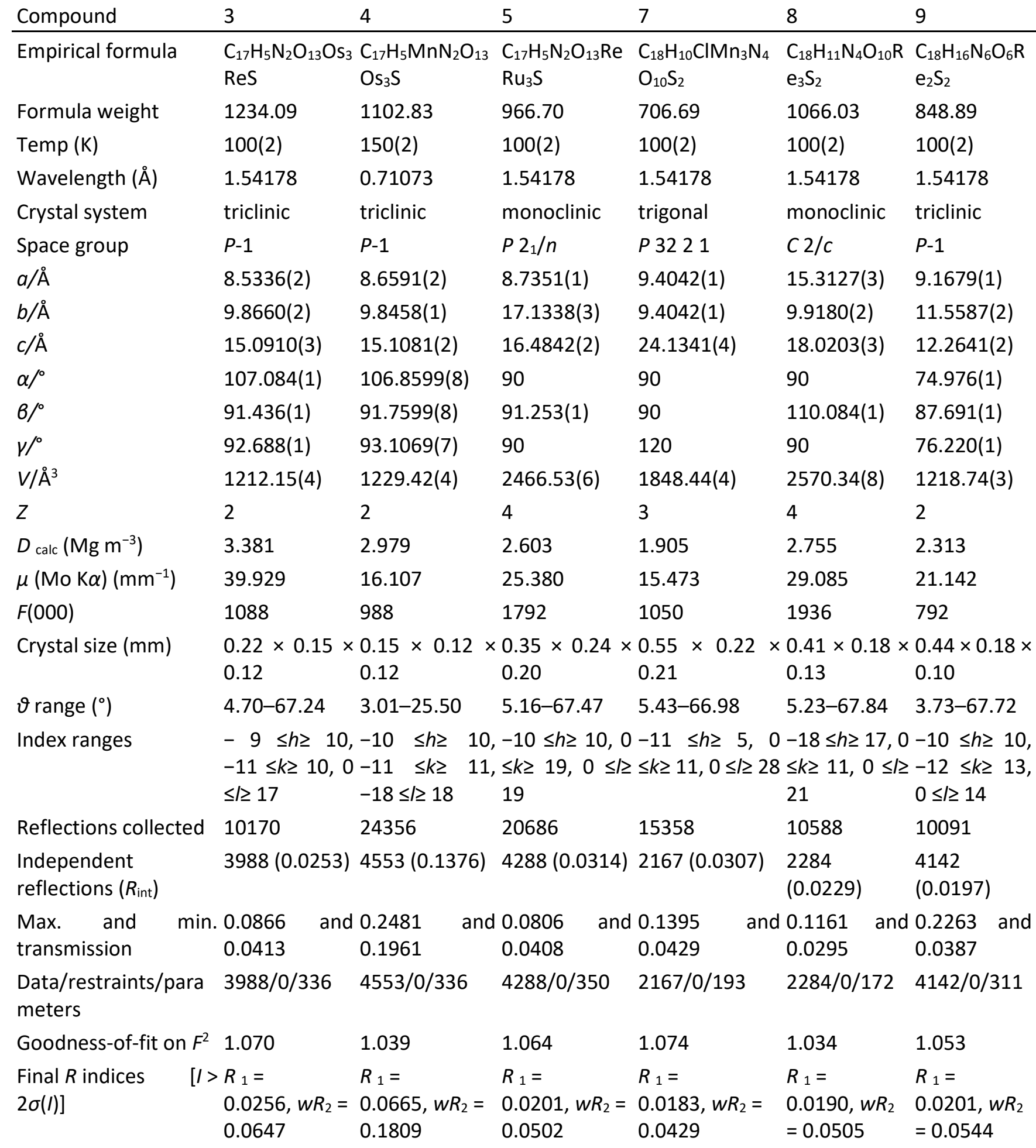




\begin{tabular}{lllllll} 
Compound & 3 & 4 & 5 & 7 & 8 & 9 \\
\hline$R$ indices (all data) & $R_{1}=$ & $R_{1}=$ & $R_{1}=$ & $R_{1}=$ & $R_{1}=$ & $R_{1}=$ \\
& $0.0277, w R_{2}=$ & $0.0679, w R_{2}=$ & $0.0214, w R_{2}=$ & $0.0187, w R_{2}=$ & $0.0191, w R_{2}$ & $0.0207, w R_{2}$ \\
& 0.0659 & 0.1840 & 0.0509 & 0.0430 & $=0.0506$ & $=0.0548$ \\
& and difference in 1.640 & and 3.290 & and 0.795 & and 0.283 & and 0.790 & and 1.009 and \\
Lak and hole $\left(\AA^{-3}\right)$ & -0.837 & -4.927 & -0.487 & -0.186 & -0.991 & -0.561
\end{tabular}

\section{Computational details}

Calculations were performed with the Gaussian 03 (G03) program package $\frac{64}{}$ employing the DFT method with Becke three parameter hybrid functional $\underline{65}$ and Lee-Yang-Parr's gradient corrected correlation functional (B3LYP). 6 Geometry optimization of 5, 7, and $\mathbf{8}$ in the gas phase was performed employing the LanL2DZ basis set. .67 No symmetry constrains were adopted in the geometry optimization of all the compounds. The nature of all stationary points was confirmed by normal mode analysis. Selected geometry parameters for $\mathbf{5}, \mathbf{7}$ and $\mathbf{8}$ are reported in the ESI. +

\section{Acknowledgements}

Part of this work was carried out by S.E.K. at the University of Goettingen. S.E.K. gratefully acknowledges the von Humboldt Foundation for a Fellowship to spend time at the University of Goettingen.

\section{References}

${ }^{1}$ (a) Selected reviews: R. D. Adams, in Comprehensive Organometallic Chemistry II, ed. E. W. Abel, F. G. A. Stone and G. Wilkinson, Elsevier, Oxford, 1995, vol. 10, pp. 1-22; (b) Y. Chi, and D. K. Hwang, in Comprehensive Organometallic Chemistry II, ed. E. W. Abel, F. G. A. Stone and G. Wilkinson, Elsevier, Oxford, 1995, vol. 10, pp. 85-185; (c) P. Braunstein and J. Rosé, inComprehensive Organometallic Chemistry II, ed. E. W. Abel, F. G. A. Stone and G. Wilkinson, Elsevier, Oxford, 1995, vol. 10, pp. 351-385

${ }^{2}$ (a) Selected papers: L. H. Gade, Angew. Chem., Int. Ed. Engl., 2000, 39, 2658-2678 ; (b) M. Herberhold and G.-X. Jin,Angew. Chem., Int. Ed. Engl., 1994, 33, 964-966 ; (c) B. Bosnich, Inorg. Chem., 1999, 38, 2554-2562.

${ }^{3}$ (a) S. Liu and G.-X. Jin, Dalton Trans., 2007, 949-954 ; (b) Y.-Q. Chen, J. Zhang, S. Cai, X.-F. Hou, H. Schumann and G.-X. Jin, J. Chem. Soc., Dalton Trans., 2007, 749-758 .

4J. N. L. Dennett, J. Jacke, G. Nilsson, A. Rosborough, M. J. Ferguson, M. Wang, R. McDonald and J. Takats, Organometallics, 2004, 23, 4478-4485 .

${ }^{5}(a)$ R. D. Adams, B. Captain and M. D. Smith, Angew. Chem., Int. Ed., 2006, 45, 1109-1112 ; (b) R. D. Adams, B. Captain and L. Zhu, Inorg. Chem., 2006, 45, 430-436.

${ }^{6} \mathrm{~T}$. Tanase and R. A. Begum, Organometallics, 2001, 20, 106-114.

${ }^{7}$ M. M. Dell'Anna, S. J. Trepanier, R. McDonald and M. Cowie, Organometallics, 2001, 20, 88-99.

${ }^{8}$ P. Mathur, A. K. Das, M. Hossain, C. V. V. Satyanarayana, A. L. Rheingold, L. M. Liable-Sands and G. P. A. Yap, J. Organomet. Chem., 1997,532, 189-199. 
${ }^{9}$ N. T. Lucas, J. P. Blitz, S. Petrie, R. Stranger, M. G. Humphrey, G. A. Health and V. Otieno-Alego, J. Am. Chem. Soc., 2002, 124, 5139-5153.

${ }^{10}$ P. Mathur, A. K. Bhunia, S. M. Mobin, V. K. Singh and C. Srinivasu, Organometallics, 2004, 23, 3694-3700.

11J. N. L. Dennett, S. A. R. Knox, K. M. Anderson, J. P. H. Charmant and A. G. Orpen, J. Chem. Soc. Dalton Trans., 2005, 63-73.

${ }^{12}$ L. Quebatte, R. Scopelliti and K. Severin, Angew. Chem. Int. Ed., 2004, 43, 1520-1524.

${ }^{13}$ (a) R. D. Adams, T. S. Barnard, Z. Li, W. Wu and J. H. Yamamato, J. Am. Chem. Soc., 1994, 116, 9103-9113;

(b) R. D. Adams and T. S. Barnard, Organometallics, 1998, 17, 2567-2573; (c) R. D. Adams and T. S. Barnard, Organometallics, 1998, 17, 2885-2890.

${ }^{14}$ A. J. Bridgeman, M. J. Mays and A. D. Woods, Organometallics, 2001, 20, 2932-2935.

${ }^{15}$ Y. Ishii and M. Hidai, Catal. Today, 2001, 66, 53-61.

${ }^{16}$ S. Gauthier, R. Scopelliti and K. Severin, Organometallics, 2004, 23, 3769-3771.

${ }^{17} \mathrm{P}$. Braunstein and J. Rosé, in Catalysis by Di- and Polynuclear Metal Clusters, ed. R. D. Adams and F. A. Cotton, Wiley, New York, 1998, pp. 443-508.

${ }^{18}$ A. M. Trzeciak and J. J. Ziolkowski, Coord. Chem. Rev., 1999, 190-192, 883-900.

${ }^{19}$ P. Kalck, Polyhedron, 1988, 7, 2441-2450.

${ }^{20}$ E. K. van den Beuken and B. L. Feringa, Tetrahedron, 1998, 54, 12985-13011.

${ }^{21} \mathrm{P}$. Braunstein and J. Rosé, In Metal Clusters in Catalysis, ed. P. Braunstein, L. A. Oro and P. R. Raithby, Wiley-VCH, Weinheim, Germany, 1999, vol. 2, pp. 616-677.

22P. R. Raithby and M. J. Rosales, Adv. Inorg. Chem. Radiochem., 1985, 29, 169-247.

${ }^{23}$ E. Sappa, A. Tiripicchio, A. J. Carty and G. E. Toogood, Prog. Inorg. Chem., 1987, 35, 437-625, and references therein.

${ }^{24}$ (a) A. Sivaramakrishna, H. S. Clayton, B. C. E. Makhubela and J. R. Moss, Coord. Chem., 2008, 252, 14601485; (b) I. Ojima, Z. Li, R. J. Donovan and P. Ingallina, Inorg. Chim. Acta, 1988, 270, 279-284.

${ }^{25}$ V. Ferrand, G. Süss-Fink, A. Neels and H. Stoeckli-Evans, J. Chem. Soc. Dalton Trans., 1998, 3825-3831.

${ }^{26}$ E. L. Muetterties, T. N. Rhodin, E. Band, C. F. Brucker and W. R. Pretzer, Chem. Rev., 1979, 79, 91-137.

${ }^{27}$ S. Ghosh, S. E. Kabir, S. Pervin, G. M. G. Hossain, D. T. Haworth, S. V. Lindeman, T. A. Siddiquee, D. W. Bennett and H. W. Roesky, Z. Anorg. Allg. Chem., 2009, 635, 76-87.

${ }^{28}$ (a) K. A. Azam, K. M. Hanif, A. C. Ghosh, S. E. Kabir, S. R. Karmakar, K. M. A. Malik, S. Parvin and E. Rosenberg, Polyhedron, 2002, 21, 885-892; (b) R. D. Dewhurst, A. R. Hansen, A. F. Hill and M. K. Smith, Organometallics, 2006, 25, 5843-5846; (c) D. J. Williams, A. M. Hutchings, N. E. McConnell, R. A. Faucher, B. E. Huck, C. A. S. Brevett and D. VanDerveer,Inorg. Chim. Acta, 2006, 359, 2252-2255.

${ }^{29}$ (a) N. A. Sanina, T. N. Rudneva, S. M. Aldoshin, G. V. Shilov, D. V. Kortchagin, Yu. M. Shulga, V. M. Martynenko and N. S. Ovanesyan,Inorg. Chim. Acta, 2006, 359, 570-576; (b) Y. Matsunaga, K. Fujisawa, N. Amir, Y. Miyashita and K. J. Okamoto, Coord. Chem., 2005, 58, 1047-1061; (c) N. A. Bell, W. Clegg, S. J. Coles, C. P. Constable, R. W. Harrington, M. B. Hursthouse, M. E. Light, E. S. Raper, C. Sammon and M. R. Walker, Inorg. Chim. Acta, 2004, 357, 2091-2099. 
${ }^{30}$ C. C. Ashworth, N. A. Bailey, M. Johnson, J. A. McCleverty, N. Morrison and B. Tabbiner, J. Chem. Soc. Chem. Commun., 1976, 743-744.

${ }^{31}$ (a) E. S. Raper, Coord. Chem. Rev., 1985, 61, 115-184; (b) H. Alper and A. S. K. Chan, Inorg. Chem., 1974, 13, 225-236.

${ }^{32}$ (a) C. C. Romão, and B. Royo, in Comprehensive Organometallic Chemistry III, ed. R. H. Crabtee, D. M. Mingos, Elsevier, Oxford, UK, 2007, vol. 5. pp. 855-960; (b) B. Krebs and G. Henkel, Angew. Chem. Int. Ed. Engl., 1991, 30, 769-788.

${ }^{33}$ (a) L. Casella, Inorg. Chem., 1984, 23, 2781-2787; (b) I. G. Dance, Polyhedron, 1986, 5, 1037-1141.

${ }^{34}$ A. J. Deeming, M. Karim, N. I. Powell and K. I. Hardcastle, Polyhedron, 1990, 9, 623-626.

${ }^{35}$ B. R. Cockerton, A. J. Deeming, M. Karim and K. I. Hardcastle, J. Chem. Soc. Dalton Trans., 1991, 431-437.

36J. Knight and M. J. Mays, J. Chem. Soc. Dalton Trans., 1972, 1022-1029.

${ }^{37}$ M. S. Corraine and J. D. Atwood, Organometallics, 1991, 10, 2647-2651.

${ }^{38}$ M. P. Jensen, W. Henderson, D. H. Johnston, M. Sabat and D. F. Shriver, J. Organomet. Chem., 1990, 394, 121-143.

${ }^{39}$ C. K. Schauer, S. Harris, M. Sabat, E. J. Voss and D. F. Shriver, Inorg. Chem., 1995, 34, 5017-5028.

${ }^{40}$ A. B. Antonova, S. V. Kovalenko, E. D. Korniyets, A. A. Johansson, Y. T. Struchkov and A. I. Yanovsky, J. Organomet. Chem., 1984, 267, 299-307.

${ }^{41}$ M. Shieh, T.-F. Tang, S.-M. Peng and G.-H. Lee, Inorg. Chem., 1995, 34, 2797-2803.

${ }^{42}$ A. D. Shaposhnikova, G. L. Kamalov, R. A. Stadnichenko, A. A. Pasynskii, I. L. Eremenko, S. E. Nefedov, Y. T. Struchkov and A. I. Yanovsky, J. Organomet. Chem., 1991, 405, 111-120.

${ }^{43}$ W. A. Herrmann, C. Hecht, M. L. Ziegler and T. Zahn, J. Organomet. Chem., 1984, 273, 323-331.

${ }^{44}$ O. Benali-Baitich, J. C. Daran and Y. Jeannin, J. Organomet. Chem., 1988, 344, 393-400.

${ }^{45}$ P. Brun, G. M. Dawkins, M. Green, R. M. Mills, J.-Y. Salaün, F. G. A. Stone and P. Woodward, J. Chem. Soc. Dalton Trans., 1983, 1357-1362.

${ }^{46}$ E. G. Tulsky and J. R. Long, Inorg. Chem., 2001, 40, 6990-7002.

${ }^{47}$ R. Dilshad, K. M. Hanif, M. B. Hursthouse, S. E. Kabir, K. M. A. Malik and E. Rosenberg, J. Organomet. Chem., 1999, 585, 100-105.

${ }^{48}$ S. E. Kabir, K. M. A. Malik, E. Molla and M. A. Mottalib, J. Organomet. Chem., 2000, 616, 157-164.

${ }^{49}$ A. J. Deeming, M. Karim, P. A. Bates and M. B. Hursthouse, Polyhedron, 1988, 7, 1401-1403.

${ }^{50}$ S. S. Al-Juaid, C. Eaborn, S. M. El-Hamruni, P. B. Hitchcock, J. D. Smith and S. E. S. Can, J. Organomet. Chem., 2002, 649, 121-127.

${ }^{51}$ A. E. Reed, L. A. Curtiss and F. Weinhold, Chem. Rev., 1988, 88, 899-926.

${ }^{52}$ S. Top, M. Gunn, G. Jaouen, J. Vaissermann, J. C. Daran and M. J. McGlinchey, Organometallics, 1992, 11, 1201-1209.

${ }^{53}$ R. D. Adams, B. Captain, M. Johansson and Jr, J. L. Smith, J. Am. Chem. Soc., 2005, 488-489.

${ }^{54}$ B. F. G. Johnson, J. Lewis and D. A. Pippard, J. Chem. Soc. Dalton Trans., 1981, 407-412.

${ }^{55}$ M. I. Bruce and P. J. Low, J. Organomet. Chem., 1996, 519, 221-222.

${ }^{56}$ SMART Version 5.628, Bruker AXS, Inc.: Madison, WI, 2003. 
${ }^{57}$ Z. Otwinowski and W. Minor, Methods in Enzymology, vol. 276, ed. C. W. Carter and R. M. Sweet,Academic Press, New York, 1996, p. 307.

${ }^{58}$ SAINT Version 6.36, Bruker AXS, Inc., Madison, WI, 2002.

${ }^{59} \mathrm{G}$. Sheldrick, SADABS Version 2.10, University of Göttingen, 2003.

${ }^{60}$ R. H. Blessing, Acta Cryst., 1995, A51, 33-38.

${ }^{61}$ Program XS from SHELXTL package, V. 6.12, Bruker AXS, Inc., Madison, WI, 2001.

${ }^{62}$ Program XL from SHELXTL package, V. 6.12, Bruker AXS, Inc., Madison, WI, 2001.

${ }^{63} \mathrm{~A}$. J. C. Wilson, (editor). International Tables for X-ray Crystallography, Volume $C$, Kynoch, Academic Publishers, Dordrecht, 1992; Tables 6.1.1.4 (pp. 500-502) and 4.2.6.8 (pp. 219-222).

${ }^{64}$ M. J. Frisch, G. W. Trucks, H. B. Schlegel, G. E. Scuseria, M. A. Robb, J. R. Cheeseman, J. A. Jr, Montgomery, T. Vreven, K. N. Kudin, J. C. Burant, J. M. Millam, S. S. Iyengar, J. Tomasi, V. Barone, B. Mennucci, M. Cossi, G. Scalmani, N. Rega, G. A. Petersson, H. Nakatsuji, M. Hada, M. Ehara, K. Toyota, R. Fukuda, J. Hasegawa, M. Ishida, T. Nakajima, Y. Honda, O. Kitao, H. Nakai, M. Klene, X. Li, J. E. Knox, H. P. Hratchian, J. B. Cross, C. Adamo, J. Jaramillo, R. Gomperts, R. E. Stratmann, O. Yazyev, A. J. Austin, R. Cammi, C. Pomelli, J. Ochterski, P. Y. Ayala, K. Morokuma, G. A. Voth, P. Salvador, J. J. Dannenberg, V. G. Zakrzewski, S. Dapprich, A. D. Daniels, M. C. Strain, O. Farkas, D. K. Malick, A. D. Rabuck, K. Raghavachari, J. B. Forestman, J. V. Ortiz, Q. Cui, A. G. Baboul, S. Clifford, J. Cioslowski, B. B. Stefanov, G. Liu, A. Liashenko, A. Piskorz, I. Komaromi, R. L. Martin, D. J. Fox, T. Keith, M. A. Al-Laham, C. Y. Peng, A. Nanayakkara, M. Challacombe, P. M. W. Gill, B. Johnson, W. Chen, M. W. Wong, C. GonzalesM. J. Frisch, G. W. Trucks, H. B. Schlegel, G. E. Scuseria, M. A. Robb, J. R. Cheeseman, J. A. Montgomery, Jr., T. Vreven, K. N. Kudin, J. C. Burant, J. M. Millam, S. S. Iyengar, J. Tomasi, V. Barone, B. Mennucci, M. Cossi, G. Scalmani, N. Rega, G. A. Petersson, H. Nakatsuji, M. Hada, M. Ehara, K. Toyota, R. Fukuda, J. Hasegawa, M. Ishida, T. Nakajima, Y. Honda, O. Kitao, H. Nakai, M. Klene, X. Li, J. E. Knox, H. P. Hratchian, J. B. Cross, V. Bakken, C. Adamo, J. Jaramillo, R. Gomperts, R. E. Stratmann, O. Yazyev, A. J. Austin, R. Cammi, C. Pomelli, J. Ochterski, P. Y. Ayala, K. Morokuma, G. A. Voth, P. Salvador, J. J. Dannenberg, V. G. Zakrzewski, S. Dapprich, A. D. Daniels, M. C. Strain, O. Farkas, D. K. Malick, A. D. Rabuck, K. Raghavachari, J. B. Foresman, J. V. Ortiz, Q. Cui, A. G. Baboul, S. Clifford, J. Cioslowski, B. B. Stefanov, G. Liu, A. Liashenko, P. Piskorz, I. Komaromi, R. L. Martin, D. J. Fox, T. Keith, M. A. Al-Laham, C. Y. Peng, A. Nanayakkara, M. Challacombe, P. M. W. Gill, B. G. Johnson, W. Chen, M. W. Wong, C. Gonzalez and J. A. Pople, GAUSSIAN 03 (Revision D.01), Gaussian, Inc., Wallingford, CT, 2004.

${ }^{65}$ A. D. Becke, J. Chem. Phys., 1993, 98, 5648-5652.

${ }^{66}$ C. Lee, W. Yang and R. G. Parr, Phys. Rev. B: Condens. Matter, 1988, 37, 785-789.

${ }^{67}$ P. J. Hay and W. R. Wadt, J. Chem. Phys., 1985, 82, 270-283. 


\section{Footnote}

† Electronic supplementary information (ESI) available: Selected geometry parameters for the DFT optimized structures and LUMO orbitals for 5. CCDC reference numbers 665809 for 3, 686167 for 4, 665810 for 5, 665806 for 7, 693306 for 8 , and crystallographic data in CIF or other electronic format see DOI:10.1039/b819226j 